\title{
DP-866
}

\section{HEAVY WATER REACTORS FOR SEA WATER DISTILLATION PLANTS}

D. S. St. JOHN

C. P. ROSS

J. W. WADE

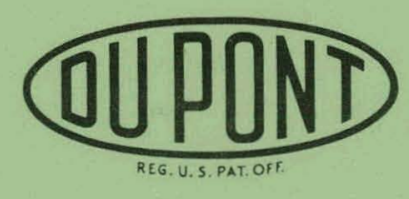

Savannah River Laboratory

Aiken, South Carolina 


\section{DISCLAIMER}

This report was prepared as an account of work sponsored by an agency of the United States Government. Neither the United States Government nor any agency Thereof, nor any of their employees, makes any warranty, express or implied, or assumes any legal liability or responsibility for the accuracy, completeness, or usefulness of any information, apparatus, product, or process disclosed, or represents that its use would not infringe privately owned rights. Reference herein to any specific commercial product, process, or service by trade name, trademark, manufacturer, or otherwise does not necessarily constitute or imply its endorsement, recommendation, or favoring by the United States Government or any agency thereof. The views and opinions of authors expressed herein do not necessarily state or reflect those of the United States Government or any agency thereof. 


\section{DISCLAIMER}

Portions of this document may be illegible in electronic image products. Images are produced from the best available original document. 
This report was prepared as an account of Government sponsored work. Neither the United States, nor the Commission, nor any person acting on behalf of the Commission:

A. Makes any warranty or representation, expressed or $1 \mathrm{mplied,}$ with respect to the accuracy, completeness, or usefulness of the information contained in this report, or that the use of any information, apparatus, method, or process disclosed in this report may not infringe privately owned rights; or

B. Assumes any liabilities with respect to the use of, or for damages resulting from the use of any information, apparatus, method, or process disclosed in this report.

As used in the above, "person acting on behalf of the Commission" includes any employee or curtractor of the Commission, or employec of such contractor, to the extent that such employee or contractor of the Commission, or employee of such contractor prepares, disseminates, or provides access to, any information pursuant to his employment or contract with the Commission, or his employment with such contractor.

Printed in USA. Price $\$ 1.25$

Available from the Office of Technical Services

U. S. Department of Commerce

Washington 25, D. C. 


\title{
HEAVY WATER REACTORS FOR SEA WATER DISTILLATION PLANTS
}

\section{by}

\author{
Dan1el S. St. John \\ Charles P. Ross \\ James W. Wade
}

.............. Approved by

D. S. St. John, Research Manager Theoretical Physics Division

$$
\text { January } 1964
$$

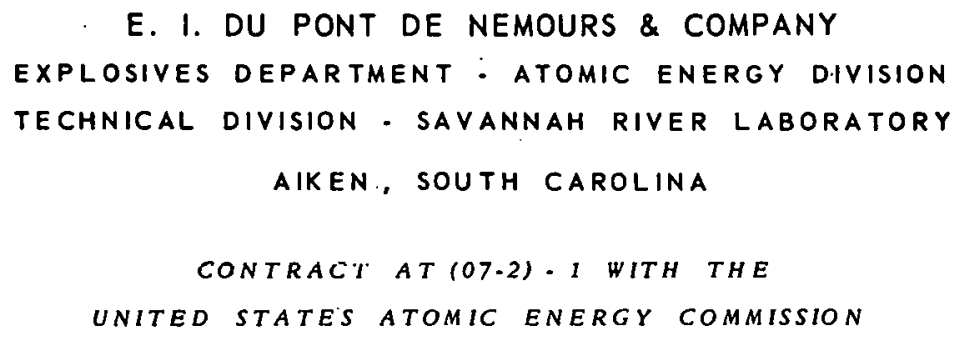




\section{ABSTRAC $\bar{T}$}

Conceptual designs of reactors moderated with $\mathrm{D}_{2} \mathrm{O}$ have been prepared for a study of the use of large reactors ror sea water distillation. Two designs are presented: a nearterm reference design producing $3500 \mathrm{MW}$ thermal with pressurized liquid $\mathrm{D}_{2} \mathrm{O}$ coolant, and a more advanced design producing $8300 \mathrm{MW}$ thermal. With organic coolant. Steam costs are estimated for dual-purpose plants in which the by-product steam from back-pressure turbines is sent to the saline water plant. These estimates show that the net steam cost varies from 11 to $164 / m i l i 10$ Btu for the 3500-MWt plant, and from 4 to $9 \not / m i l l i o n$ Btu for the $8300-$ MWt plant, as the power credit changes from 3 to $1 \mathrm{mill} / \mathrm{kwh}$. 


\section{CONTENTS}

Page

List of Tables .

List of Figures 4

Introduction $\quad 7$

Summary 8

Discussion . . . . 1-1

1. Bases for Study 1-1

1.1 General $1-1$

1.2 Reactor Coolants $1-1$

1.3 Steam Conditions $1-2$

1.4 Reactor Costs and Financ1ng $1-2$

1.5 Fuel Costs and Financ1ng $1-2$

2. 3500-MWt Reference Design 2-1

2.1 Core Désign 2-1

2.2 Reactor Tank and Shield Design 2-5

2.3 Hydraulics and Heat Transfer 2-5

2.4 Turbine Plant 2-7

2.5 Containment 2-11

2.6 Coolant Treatment. 2-1I

2.7 Reactor Plant Auxil1ary Systems 2-11

3. 8300-NWt Reference Design 3-1

3.1 Core Design 3-1

3.2 Reactor Tank and Shield Desigr $3-4$

3.3 Hydraulics and Heat Transfer 3-4

3.4 Turb1ne Plant 3-4

3.5 Containment 3-6

3.6 Reactor Plant Aux1l 1ary Systems 3-6

3.7 Development Work Required 3-7

4. Other 3500-MWt Designs 4-1

4.1 Organic-Cooled Reactor. 4-1

4.2 Bolling- $\mathrm{H}_{2} \mathrm{O}$-Cooled Reactor 4-1

4.3 Llquid- $\mathrm{D}_{2} \mathrm{O}$-Cooled Reactor for Process Heat
Only $4-5$

Appendix A $\quad A-1$

$\begin{array}{ll}\text { Appendix B } & \text { B-1 }\end{array}$

B1bllography $\mathrm{C}-1$ 


\section{LIST' OF TABLES}

Table

Page

I Reactor Design Summary

II Reactor Cost Summary 9

III Fuel Cost Summary 9

IV Steam Cost Summary 10

V Steam Cost Comparison of Reactor Types 11

VI Effest of Hilel Cycle Parameters on Steam Costa 12

2.1 Design Parameters for 3500-MWt Liquid-D $\mathrm{D}_{2} \mathrm{O}$-Cooled Reactor

3.1 Design Parameters for 8300-MWt Organic-Cooled Reactor

4.1 Design Parameters for 3500-MWt Organic-Cooled Reactor

4.2 Design Parameters for 3500-MWt Bolling- $\mathrm{H}_{2} \mathrm{O}$ Cooled Reactor

$4-2$

4.3 Design Parameters for 3500-MWt Process Heat Reactor

$4-5$

B.1 Reactor Designs and Priliminary Costs ' B-I

B.2 Preliminary Fuel Cycle Costs $\quad \cdot$ B.7

B.3 Fuel Cycle Characteristics B-8 


\section{LIST OF FIGURES}

F1gure

Page

2.I Reactor Tank Des1gn for Insulated Pressure Tubes

$2-2$

2.2. Fuel Assembly for LIquid- $\mathrm{D}_{2} \mathrm{O}$-Cooled Reactor

$2-3$

2.3. Core Layout for 3500-MWt Liqu1d- $\mathrm{D}_{2} \mathrm{O}$-Cooled Reactor

$2-4$

2.4 Flow Diagram for 3500-MWt Liqu1d-D $\mathrm{D}_{2} \mathrm{O}$-Cooled Plant

$2-6$

2.5 General Arrangement Plan "A-A" - Turbine Building - 3500-MWt Liquid- $\mathrm{D}_{2} \mathrm{O}$-Cooled Plant

$2-8$

2.6 General Arrangement Plan "B-B" - Turbine Building - 3500-MWt Liquid- $\mathrm{D}_{2} \mathrm{O}$-Cooled Plant 2-9

2.7 General Arrangement Sections - Turbine Building - 3500-MWt Liquid- $\mathrm{D}_{2} \mathrm{O}$-Cooled Plant 2-10

2.8 General Arrangement Plan - Reactor Bullding 3500-MWt Liquid- $\mathrm{D}_{2} \mathrm{O}$-Cooled Plant

2.9 General Cross Section "A-A" - Reactor Building - 3500-MWt Liquid- $\mathrm{D}_{2} \mathrm{O}$-Cooled Plant 2-13

2.10 General Cross Section "B-B" - Reactor Building - 3500-MWt Liquid- $\mathrm{D}_{2} \mathrm{O}$-Cooled Plant 2-14

3.1 Fuel Assembly for Organ1c-Cooled Reactor 3-2

3.2 Core Layout for 8300-MWt Organic-Cooled Reactor 3-3

3.3 Flow Diagram for 8300-MWt Organic-Cooled Plant 3-5

3.4 General Arrangement Plan.- Turbine Butlding 8300-MWt Organ1c-Cooled Plant

3.5 General Arrangement Plan "A-A" - Reactor Building - 8300-MWt Organic-Cooled Plant

3.6 General Arrangement Sections "B-B" and "C-C" Reactor Bullding - 8300-MWt Organic-Cooled Plant 3-10

4.1 Fuel Assembly for Bolling- $\mathrm{H}_{2} \mathrm{O}$-Cooled Reactor 4-3

4.2 Flow Diagram of Boiling- $\mathrm{H}_{2} \mathrm{O}$-Cooled Plant : 4-4 


\section{THIS PAGE \\ WAS INTENTIONALLY \\ LEFT BLANK}

$-6-$ 


\section{HEAVY WATER REACTORS FOR SEA WATER DISTILLATION PLANTS}

\section{INTRODUCTION}

In April 1963, the Division of Reactor Development, USAEC, asked the Du Pont Company, Atomic Energy D1vision, to participate in a study of dual-purpose reactors designed to produce steam suitable for the generation of electricity with the primary objective of providing process heat for a sea water distillation plant by using the exhaust steam from the turbines. This study was requested by the office of science and Technology Task Group and was belng conducted by a Subcommittee with representatives from the office of Saline water and Bureau of Reclamation of the Department of the Interior, the Federal Power Commission, and the Division of Reactor Development of the Atomic Energy Commission (DRD).

Two reactor designs were submitted by Du Pont for inclusion in the study:

- A 3500-MWt reactor, moderated and cooled with $\mathrm{D}_{2} \mathrm{O}$, that could be built with a minimum of development effort.

- An 8300-MWt reactor, moderated with $\mathrm{D}_{2} \mathrm{O}$ and cooled with organic, that would require a large amount of development work, could be constructed in the mid-70's, and represented better long-range economic potential.

Specifications were obtained for these reactor plants with the help of a reactor design and cost code prepared as part of the study program of heavy-water-moderated power reactors $(1,2)$. The results were given to the Du Pont Engineering Department and to Sargent and Lundy, Engineers, for refinement of the mechanical design and cost estimates. This information was then transmitted to the Bechtel Corporation, the architectengineer for all reactor concepts considered in the study. The fuel design for the 8300-MWt reactor was transmitted to ORNL for evaluation of the fuel cycle costs.

Subsequently the DRD requested that a 3500-MWt organiccooled design be submitted as a companion to the 8300-MWt design. This organic-cooled design replaces the 3500-MWt $\mathrm{D}_{2} \mathrm{O}$-cooled design in Bechtel's final report.

Further studies are being made by the Du Pont Engineering Department and Sargent and Lundy on the design features and the economic feastbility of $\mathrm{D}_{2} \mathrm{O}$ - and organic-cooled reactor plants in 3500- and 8300-MWt sizes.

This report presents the reactor designs and assumptions as they were submitted to the Division of Reactor Development and to Bechtel corporation. 


\section{SUMMARY}

Designs were prepared and submitted for evaluation of two reactors: a 3500-MWt reactor. cooled with l1quid $\mathrm{D}_{2} \mathrm{O}$ upon which engineering design could start immediately, and an 8300-MWt organic-cooled reactor for completion in the mid-70's. Both reactors have a cylindrical shape with vertical fuel assemblies consisting of three concentric fuel tubes contained inside. zirconium alloy pressure tubes. The liquid- $\mathrm{D}_{2} \mathrm{O}$-cooled reactor has fuel of slightly enriched ( $1.2 \% \mathrm{U}^{235}$ ) $\mathrm{UO}_{2}$ clad in zircaloy, and the organic-cooled reactor has natural uranium carbide tubes clad in Sintered Aluminum Product (SAP). A summary of the design parameters is given in Table $I$.

\section{TABILE I}

Reactor Design Summary

Reactor power, MWt

Fuel

$U^{235}$ enrichment

Coolant pressure, psi

Core length, ft

Number of fuel positions

Coolant. outlet temperature, ${ }^{\circ} \mathrm{C}$

Coolant inlet temperature, ${ }^{\circ} \mathrm{C}$

Power of average flat zone: assembly, MWt

Maximum fuel temperature, ${ }^{\circ} \mathrm{C}$

Maximum fuel rating $\left(\int k d \theta\right)$, watts $/ \mathrm{cm}$

Maximum sheath temperature, ${ }^{\circ} \mathrm{C}$

Maximum heat flux, $\mathrm{pcu} /(\mathrm{hr})\left(\mathrm{ft}^{2}\right)$

Average fuel exposure, MWD/tonne U

Steam pressure at turbine throttle, psia 650(sat.)

Gross electrical output, MW

Net electrical output, MW

Steam pressure at turbine outlet, psia

Steam temperature at turbine outlet, ${ }^{\circ} \mathrm{F}$

Process steam generated, $10^{\circ} \mathrm{Btu} /$ day

\section{$3500 \quad 8300$ \\ $\mathrm{UO}_{2} \quad \mathrm{UC}$}

$1.2 \%$ Natural

1700 . 300

1520

$420 \quad 1400$

$304 \quad 380$

264280

$9.8 \quad 6.3$

$1800 \cdots \quad 604$.

$38 \quad-$

$330 \cdot 470$

467,000 332,000

$15,000 \quad 8,500$

$620 \quad 1330$

$550 \quad 1190$

4595

$274 \quad 324$

$240 \cdot 580$

(a) $160^{\circ} \mathrm{F}$ superheat 
The construction costs were estimated in terms of 1963 dollars with labor costs and site conditions typical of a southern California coastal site. Our preliminary estimates of these costs are presented in Table II. Interest on money borrowed during construction is not included.

TABLE II

Reactor Cost Summary

(Costs in Thousands of Dollars)

$\begin{array}{lrr}\text { Reactor power, MWt } & 3500 & 8300 \\ \text { Direct labor and material costs } & & \\ \text { Reactor and primary coolant system } & 27,300 & 72,800 \\ \text { Turbine plant } & 28,000 & 67,500 \\ \text { Auxiliary fac1lities } & \frac{19,600}{74,900} & \frac{28,800}{169,100} \\ \text { Total direct costs } & \frac{41,200}{16,100} & \frac{93,000}{262,100} \\ \text { Indirect costs (55\%) } & 29,000 & 33,000 \\ \text { Total capital costs } & & \\ D_{2} \text { O Inventory } & \end{array}$

Preliminary fuel costs for the near-term 3500-MWt reactor and the mid-70's 8300-MWt reactor are given in Table III. Fuel fabrication costs were estimated on the basis of the construction and operation of a privately owned fuel fabrication plant designed to produce fuel for the single reactor. Fuel reprocessing charges were estimated from Nuclear Fuel Services charges for the 3500-NWt plant and on the basis of a hypothetical two-ton-per-day fuel reprocessing plant for the 8300-MWt design. Uranium costs correspond to toll enrichment with separative work charges of $\$ 30 / \mathrm{kg}$ U and a. $\mathrm{U}_{3} \mathrm{O}_{8}$ price of $\$ 5 / \mathrm{Ib}$. In the 8300-MWt case the reprocessing cost is low enough so that the plutonium credit $(\$ 6.70 / \mathrm{g}$ Pu) provides a significant subsidy, whereas for the 3500-MWt case, the reprocessing charges and plutonium credit are approximately equal.

\section{TABLE III}

Fuel Cost Summary

(Fuel costs in $\$ / \mathrm{kg}$ of $\mathrm{U}$ )

$\begin{array}{lcc}\text { Reactor power, MWt } & 3500 & 8300 \\ \mathrm{U}^{235} \text { enrichment } & 1.2 \% & \text { Natural } \\ \text { Fuel exposure, MWD/tonne } & 15,000 & 8,500 \\ \text { Fuel fabrication cost } & 38.80 & 16.80 \\ \text { Cost of uranium } & 48.91 & 13.00 \\ \text { Shipping and reprocessing } & 35.30 & 17.50 \\ \text { Inventory } & 5.07 & 1.62 \\ \text { Plutonium credit } & (35.20) & (28.40) \\ \text { Net fuel costs } & 92.88 & 20.52\end{array}$


The reactor designs were optimized for fixed charge rates typical of municipai, state, or federal ownership, as specified by the Task Group, of $7.3 \%$ for depreclating and $5.0 \%$ for nondepreciating capital items. The reactor is to have a $90 \%$ avallability and the combined plant, a load factor of $80 \%$. With these assumptions the cost of steam to the desalination plant as a function of a price at which power can be sold is summarized in Table IV.

\section{TABLE IV \\ Steam Cost Summary \\ (Steam Costs, \&/milion Btu)}

\begin{tabular}{|c|c|c|}
\hline Reaotor power, NWt & 3500 & 83,00 \\
\hline Capital charges & 12.1 & 11.2 \\
\hline $\mathrm{D}_{2} \mathrm{O}$ inventory sharges & 2.1 & $1: 0$ \\
\hline Operating charges & 3.0 & 1.5 \\
\hline $\mathrm{D}_{2} \mathrm{O}$ losses or organtc makeup & 0.8 & 1.6 \\
\hline Fuel cycle costs. & 9.3 & 3.4 \\
\hline Total costs & $27 \cdot 3$ & 18.7 \\
\hline Power credit at $1 \mathrm{~m} / \mathrm{kwh}$ & 5.5 & 4.9 \\
\hline Net steam costs & 16.3 & 8.9 \\
\hline Power credit at $3 \mathrm{~m} / \mathrm{kwh}$ & 16.5 & 14.7 \\
\hline Net steam costs & 10.8 & 4.0 \\
\hline
\end{tabular}

Additional reactor designs were prepared for study purposes with the design and cost computer code: (1) a 3500-NWt organiccooled design, and (2) a 3500-MWt bolling- $\mathrm{H}_{2} \mathrm{O}$-cooled design for comparison with the design proposed by the Oak Ridge National Laboratory (4). Preliminary cost estimates for these designs are compared with the reference designs in Table $V$. The 3500-MWt organic-cooled design was used rather than $11 q u i d-\mathrm{D}_{2} \mathrm{O}-$ cooled design in Bechtel's final report.

Also included for comparison is a low pressure liquid- $\mathrm{D}_{2} \mathrm{O}-$ cooled reactor(1) designed to produce 3500 MWt of low pressure steam and no electricity. Its net steam cost of about $20 \not / 10^{6}$ Btu represents an upper limit for reactors of this size, and shows that the incentive to build dual-purpose reactors depends on a satisfactory credit for the electricity produced. The relatively small capital charges of this steam-only system 
result primarliy from eliminating the turbine plant and reducing the wall thickness of the pressure tubes, piping, steam generators; and contalnment bullding. The large operating charges include buying the electrical power to run the plant.

TABLE V

Steam Cost Comparison of Reactor Types

\begin{tabular}{|c|c|c|c|c|c|}
\hline Reactor power, MWt & 3500 & 3500 & 3500 & 3500 & 8300 \\
\hline Coolant & Ilquid $\mathrm{D}_{2} \mathrm{O}$ & Liquid $\mathrm{D}_{2} \mathrm{O}$ & Bolling $\mathrm{H}_{2} \mathrm{O}$ & Organ1c & Organ1c \\
\hline System pressure, psia & $300^{(a)}$ & 1700 & 1500 & 300 & 300 \\
\hline Steam costs, $\not /$ million Btu & & & & & \\
\hline Capital charges. & 4.7 & 12.1 & 14.9 & 14.2 & 11.2 \\
\hline $\mathrm{D}_{2} \mathrm{O}$ inventory charges & 1.7 & 2.1 & 1.4 & 1.3 & 1.0 \\
\hline Operating charges & 5.5 & 3.0 & 3.3 & 3.1 & 1.5 \\
\hline $\mathrm{D}_{2} \mathrm{O}$ losses and organic makeup & 0.7 & 0.8 & 0.2 & 1.8 & 1.6 \\
\hline Fuel cycle costs & 7.1 & 9.3 & 12.8 & 9.3 & 3.4 \\
\hline Total costs & 19.7 & $27 \cdot 3$ & 32.6 & $29 \cdot 7$ & 18.7 \\
\hline $\begin{array}{l}\text { Power credit at } 3.0 \\
\mathrm{~m} / \mathrm{kwh}\end{array}$ & - & 16.5 & 24.6 & 19.2 & 14.7 \\
\hline Net steam costs & 19.7 & 10.8 & 8.0 & 10.5 & 4.0 \\
\hline
\end{tabular}

(a) Process heat only

The 3500-MWt Iiquid- $\mathrm{D}_{2} \mathrm{O}$-cooled design has a relatively high enrichment ( $\left.1.2 \% \mathrm{U}^{235}\right)$ optimized for near-term estimates of zirconium, fuel fabrication, and fuel reprocessing costs. It would probably be economical to store the spent fuel until the fuel reprocessing industry grows to the point at which more economical recovery of the plutonium in the spent fuel is possible. As these costs are reduced, savings will be made by reducing the fuel enrichment, fuel burnup costs, and average. fuel exposure.

The 8300-MWt organic-cooled design uses cast UC fuel tubes. Fuel cycle studies were made with cast UC rods and with mechanically compacted $\mathrm{UO}_{2}$ tubes as alternative fuels and with slightly enriched uranium rather than natural uranium. Table VI lists the effect of changes in fabrication and reprocessing costs and in plutonium buy-back credit on the fuel cycle costs for each of these cases. 


\section{TABLE VI}

Effect of Fuel Cycle Parameter on Steam Costs

(8300-MWt Organic-Cooled

Heavy Water Reactor, Municipal Financing)

\section{Fuel type}

Enrichment, \% $\mathrm{U}^{235}$ :

Fuel cycle costs, $\$ / \mathrm{kg} U$

Exposure, MWD/kg

Fuel cycle component of the steam cost, $\phi / 10^{6}$ Btu

Réference design.

Eৎৎeul Uৎ:

Increased fabrication cost, $\$ 5 / \mathrm{kg}$

Increased reprocessing cost, $\$ 5 / \mathrm{kg}$

Increased $\mathrm{Pu}$ credit, $\$ 1 / \mathrm{g}$

\begin{tabular}{|c|c|c|c|c|}
\hline $\mathrm{UC}$ & Tubes & UC & Rods & $\mathrm{UO}_{3}$ Tubes \\
\hline 0.7 & $1: 2$ & $0.7^{\circ}$ & 1.2 & 1.2 \\
\hline 19.6 & 73.6 & $25 \cdot 5$ & 79.5 & 72.1 \\
\hline 8.5 & $17: 0$ & 8.5 & 17.0 & 15.0 \\
\hline 3.4 & 6.5 & 4.5 & 7.9 & 8.1 \\
\hline 0.9 & 0.4 & 0.9 & 0.8 & 0.6 \\
\hline 0.9 & 0.4 & 0.9 & 0.8 & 0.6 \\
\hline-0.6 & -0.3 & -0.6 & -0.4 & -0.4 \\
\hline
\end{tabular}




\section{DISCUSSION}

\section{BASES FOR THE STUDY}

\subsection{GENERAL}

The reactor station ground rules as presented by the office of Science and Technology Task Group (3) for this study are shown in Appendix A. Since the orlginal set of ground rules on which these $D_{2} O$ reactor designs are based were altered, these designs are not completely consistent with the ground rules on such 1tems as the turbine back pressure and temperature rise across the brine heaters (Ground Rule No. 2). These differences have been accounted for in the comparison study by Bechtel Corporation(3).

The entire study was carried out in a period of about eight weeks which required that maximum use be made of information that was already developed as part of the Du Pont heavy water power reactor program. This $11 \mathrm{mlt}$. of optimization and design that could be accomplished to suit these reactors to this particular purpose. The reactor design and cost code at the Savannah River Laboratory was used to obtain the core designs and the preliminary reactor cost estimates for 3500-MWt reactors (about the upper l1m1t of the cost equations used in the code). The reactor core design and operating conditions for the 8300-MWt design were selected largely on the basis of studies made in the smaller sizes.

\subsection{REACTOR COOLANTS}

With heavy water reactors a wide choice of possible coolants is avallable tncluding bolling and liquid $\mathrm{D}_{2} \mathrm{O}$ and $\mathrm{H}_{2} \mathrm{O}$, organtc t'luids, and gas.

For the 3500-MWt reactor, l1quid $\mathrm{D}_{2} \mathrm{O}$ coolant was selected since this represents the concept upon which construction could be. started immediately with a minimum of development effort. This coricept minimizes the total cost of building a single reactor to be on-line by 1968 .

For the 8300-MWt reactor to be on-line by 1975, both organic and bolling $\mathrm{H}_{2} \mathrm{O}$ (as proposed by ORNL (4)) appear to have equivalent potential for lowest costs for these plants. The reactor design selected for this study is organic-cooled primarliy because more consideration has been given to this concept in the Du Pont program, so that reactor designs in this size were more readily available for this study. If such a reactor were to be constructed, elther coolant concept could be employed and both would presumably be preceded by a smaller prototype designed to go or-l1ne in 1969 or 1970. 


\subsection{STEAM CONDITIONS}

The reactor is designed primarily to produce steam for the desalination $\mathrm{plant}$ and as such the steam temperature to the desalination plant was specified in the ground rules to provide maximum sea water temperatures of $250^{\circ} \mathrm{F}$ for the 3500-MWt plant, and temperatures of 250,300 , and $350^{\circ} \mathrm{F}$ for the 8300-MWt plant. Within the se restrictions it is expected that the sale of electricity will represent a significant subsidy to the cost of generating process steam so the reactors are designed to produce steam to the turbine throttle at about the maximum conditions consistent with the technology expected at the spec1fled completion dates.

If power is sold at more than $2 \mathrm{~m} / \mathrm{kwh}$ the cost of steam to the desalination plant could be reduced by reducing the turblne back pressure and increasing the amount of electriclity generated. A complete optimization for a particular plant would require a knowledge of the cost of producling water as a function of the temperature of the steam supplied to the desalination plant as well as the sales price expected for the electricity.

\subsection{REACTOR COSTS AND FINANCING}

The reactors are optimized as specifled in the ground rules for annual fixed charge rates of $7.3 \%$ for depreclating and $5.0 \%$ for nondepreclating capital 1tems. Steam costs are also calculated, as a matter of interest, for charge rates of $14.1 \%$ for depreclating and $12.5 \%$ for nondepreclating 1tems. Heavy water 1 s assumed to cost $\$ 20 / 1 \mathrm{~b}$ and to be a nondepreciating 1tem. All costs are expressed in 1963 dollars, and labor, productivity, and wages are representative of a southern California site.

If the reactor were designed for the higher charge rates the optimum system would have a higher power rating from the core at the expense of somewhat increased fuel cycle costs. Examples of 300-MWe power reactor plants optimlzed for these two types of charge rates have been developed as part of the heavy water power reactor program $(5,6)$.

\subsection{FUEL COSTS AND FINANCING}

For the 3500-MWt reactor the fuel fabrication costs are based upon the current estimated costs of supplying such fuel, assuming that all the fuel for the reactor is supplied by one fuel fabricator: The reprocessing costs are based on those quoted for the Nuclear Fuel Services plant. These relatively high fabrication and reprocessing costs lead to 
a relatively high enrichment ( $1.2 \% U^{235}$ ) and fuel exposure. The spent fuel has a $U^{235}$ concentration below $0.25 \%$ (assumed diffusion plant tails). Reprocessing depends upon plutonium values belng h1gh enough to pay the reprocessing costs.

For the 8300-MWt plant the fuel fabrication costs are based on those calculated for a one-ton-per-day fabrication plant capitalizing its investment at a 15\% flxed charge rate. Spent fuel processing costs are based upon those for a two-ton-. per-day reprocessing plant and the value of plutonium is $\$ 6.70 / \mathrm{g}$ in nitrate solution. For these conditions it is about a toss-up whether to use relatively short-lived natural uranium fuel or slightly enriched fuel with increased exposure. The natural fuel cycle was chosen for the reference case because later in the reactor $11 f e$, it is presumed that fuel fabrication and reprocessing charges would go down while the plutonium credit may increase. Each of these factors would make the natural uranium fuel cycle relatively more economical.

The type of financing used in handling the fuel inventory does not affect the optimum fuel cycle because the fuel inventory charges are such a small 1 tem for heavy water reactors. 


\section{2. $3500-M W+$ REFERENCE DESIGN}

\subsection{CORE DESIGN}

\section{General}

The major design parameters for the liquid- $\mathrm{D}_{2} \mathrm{O}$-cooled 3500-MWt reactor are listed in Table 2.1. This is a vertical reactor in which the primary coolant flows upward past 420 fuel assemblies contained in pressure tubes (Figure 2.1). The $\mathrm{D}_{2} \mathrm{O}$ moderator outslde the pressure tubes is at low pressure and temperature. Complete design and preliminary cost data are given in Appendix B.

The design includes all the auxiliary facilities, structures, and land required for the reactor and turbinegenerator plant.

\section{TABLE 2.1}

Design Parameters for 3500-MWt Itiquid-D,O-Cooled Reacior

\begin{tabular}{|c|c|c|c|}
\hline \multirow{3}{*}{\multicolumn{2}{|c|}{$\begin{array}{l}\text { Fuel } \\
U^{235} \text { enrichment, wt } \% \\
\text { Coolant pressure, psi }\end{array}$}} & & $\mathrm{UO}_{2}$ Tubes \\
\hline & & & 1.19 \\
\hline & & & 1700 \\
\hline \multicolumn{3}{|c|}{ Core length, ft } & 15 \\
\hline \multicolumn{3}{|c|}{ Number of fuel positions } & 420 \\
\hline \multicolumn{3}{|c|}{ Reactor power, MW to steam generators } & 3524 \\
\hline \multicolumn{3}{|c|}{ Coolant outlet temperature, ${ }^{\circ} \mathrm{C}$} & 304 \\
\hline \multicolumn{3}{|c|}{ Coolant inlet temperature, ${ }^{\circ} \mathrm{C}$} & 264 \\
\hline \multicolumn{3}{|c|}{ Power of average flat zone assembly, MWt } & 9.8 \\
\hline \multicolumn{3}{|c|}{ Maximum fuel rating $\left(\int \mathrm{kd} \theta\right)$, watts/cm } & 38 \\
\hline \multicolumn{3}{|c|}{ Maximum sheath temperature, ${ }^{\circ} \mathrm{C}$} & 330 \\
\hline \multicolumn{3}{|c|}{ Maximum heat flux, pcu/(hr) $\left(t^{\prime} t^{2}\right)$} & 467,000 \\
\hline \multicolumn{3}{|c|}{ Average fuel exposure, MWD/tonne $U$} & 15,000 \\
\hline \multicolumn{3}{|c|}{ Steam pressure at turbine throttle, psia } & 650 \\
\hline & & $\begin{array}{l}\text { Electricity } \\
\text { Only } \\
\end{array}$ & $\begin{array}{l}\text { Electricity } \\
\text { and Steam }\end{array}$ \\
\hline Gross e & lectrical output, MW & 1090 & 620 \\
\hline Net ele & etrical output, MW & 1000 & .550 \\
\hline Steam $\mathrm{g}$ & enerated, $10^{\circ} \mathrm{Btu} / \mathrm{day}$ & - & 240 \\
\hline Steam $\mathrm{p}$ & ressure at turbine outlet & $1.5^{\prime \prime} \mathrm{Hg}$ & $45 \mathrm{ps} 1 \mathrm{a}$ \\
\hline Steam $t$ & emperature at turbine outlet, ${ }^{\circ} \mathrm{F}$ & 92 & 274 \\
\hline
\end{tabular}




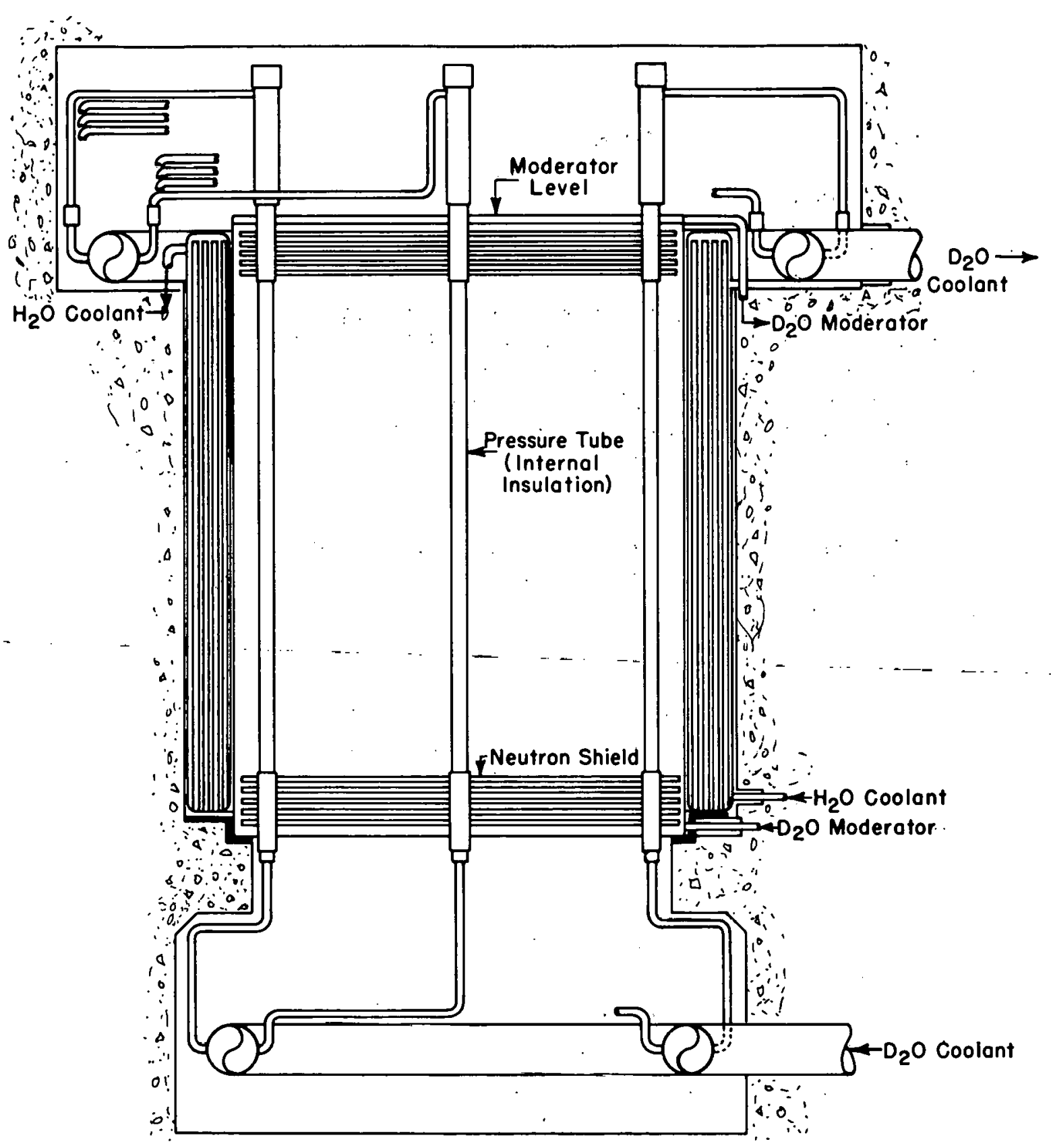

FIG. 2.1 REACTOR TANK DESIGN FOR INSULATED PRESSURE TUBES

\section{Fuel Assembly}

The Ilquid- $\mathrm{D}_{2} \mathrm{O}$-cooled fuel assembly (Figure 2.2) consists of three concentric tubes of $\mathrm{UO}_{2}$ enriched to $1 . .19 \% \mathrm{U}^{235}$. Each assembly contains 300 pounds of $\mathrm{UO}_{2}$. The tubes are $7-1 / 2$ feet long and are fabricated by vibratory compaction followed by swagling. The tubes are clad with 0.020 inch of Zircaloy and have the following dimensions:

Fuel Tube No. Clad OD, in. Clad ID, In.

$\begin{array}{ccc}1: 3.70 & 3.24 \\ 2 & 2.57 & 2.01 \\ 3 & 1.27 & 0.68 \\ & 2-2 & \end{array}$




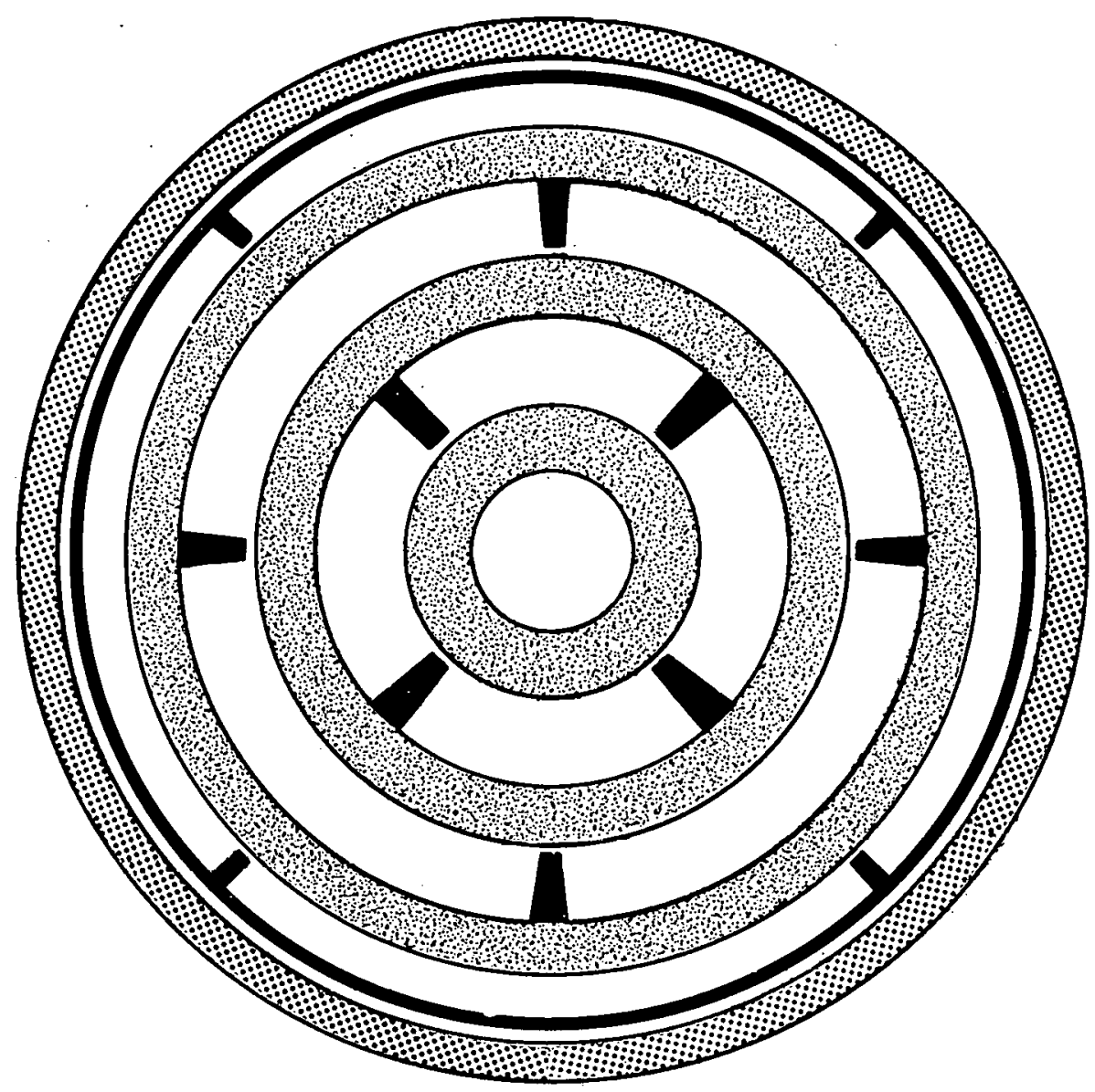

Full. Scale

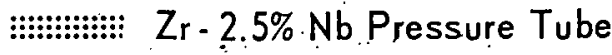

Zircaloy Insulating Liner

\%क Vibratory Compacted $\mathrm{UO}_{2}$ Fuel Tubes Clad with 0.020 "' of Zircaloy

FIG. 2.2 FUEL ASSEMBLY FOR LIQUID-D ${ }_{2}$ O-COOLED REACTOR

Spacing ribs are attached to the inner sheaths of the outer two fuel tubes by electron beam welding before the $\mathrm{UO}_{2}$ is loaded into the sheaths.

The assembly is designed for the same coolant temperature rise in each channel and for equal burnout safety factors on each fuel tube.

\section{Pressure Tube}

The pressure tubes are cold-worked zirconium - $2.5 \%$ nlobium tubes to which stainless steel end fittings are attached by tandem-extruded joints. Tube thickness is based on a design stress that is one-fourth of the ultimate tensile strength. Heat losses from the coolant to the moderator are 


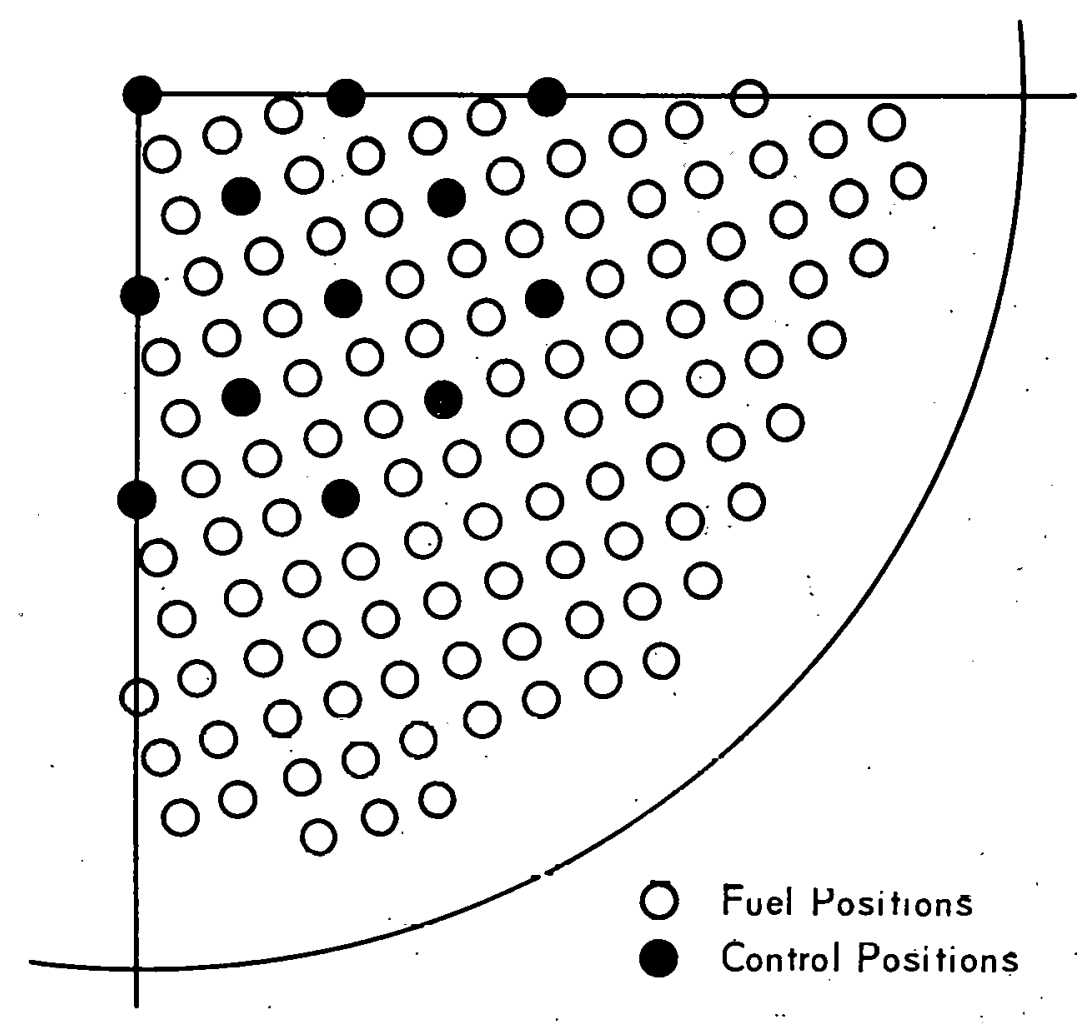

FIG. 2.3 CORE LAYOUT FOR 3500-MW+ LIQUID-D 20 -COOLED REACTOR

minimized by an insulating annulus of stagnant $\mathrm{D}_{2} \mathrm{O}$ inside the pressure tube. The annulus and the outer coolant channel are defined by a Zircaloy insulating liner that has spacing ribs attached to 1ts ID by electron beam welding. The insulating liner also supports the fuel column, and the whole, assembly can be removed from the pressure tube if necessary by withdrawing the IIner.

\section{Lattice Design}

Figure 2.3 shows one quadrant of the reactor core. The core contalns 420 fuel assemblies on a 10-inch square pitch, is 15 feet long and 20 feet in diameter, and has a 20-inch $\mathrm{D}_{2} \mathrm{O}$ reflector surrounding the core and 24 -1nch reflectors at each end.

Reactor control is provided by top-mounted, mechanically actuated control rods. The 37 control clusters are in lattice positions, and each contains the equivalent of $2-1 / 2$ rods. The rods provide axial and radial flattening of the reactor as well as power control.

There are 40 safety rods in interstitial positions (not shown in Figure 2.3). These rods are fully withdrawn above the core when the reactor is operating, and fall by gravity to shut the reactor down. 


\section{Fuel Cycle}

Interim replacement of the fuel is required if reactivity is to be maintained for long fuel exposures. A workable charging scheme for this reactor is to replace one-third of the fuel assemblies from both the flat and buckled zones at each planned shutdown. The average exposure for an initial enrichment of $1.19 \%$ is 15,000 MWD/tonne U (17,000 in flat zone and 13,000 in buckled zone). Energy generation costs do not increase greatly if the design exposure is decreased, because the required fuel enrichment also decreases.

The optimum refueling scheme might include charging fresh fuel to the buckled zone for a cycle and then to the flat zone for a cycle, or providing a higher enrichment in the buckled zone.

\subsection{REACTOR TANK AND SHIELD DESIGN}

The $\mathrm{D}_{2} \mathrm{O}$ moderator is contained in a stainless steel tank to which the pressure tubes are welded. The tank also contains the top and bottom thermal shields, which are simply plates of stainless steel separated by $\mathrm{D}_{2} \mathrm{O}$. The radial thermal shield consists of an annular carbon steel tank that contains carbon steel plates cooled by $\mathrm{H}_{2} \mathrm{O}$ (Figure 2.1). Heat produced in the moderator and shields can be used to preheat sea water for the distillation plant.

\subsection{HYDRAULICS AND HEAT TRANSFER}

A process flow diagram of the plant is shown in Figure 2.4. The primary coolant system consists of eight loops, each containing one pump and one vertical U-tube steam generator. Coolant is distributed to the pressure tubes by headers and plgtails as shown in Figure 2.1. Essentially all the primary piping and equipment are constructed of carbon steel. To attain the highest possible steam temperature, about $15 \%$ of the total heat transfer area is in an economizer in which the secondary feedwater is heated to the boiling point. 


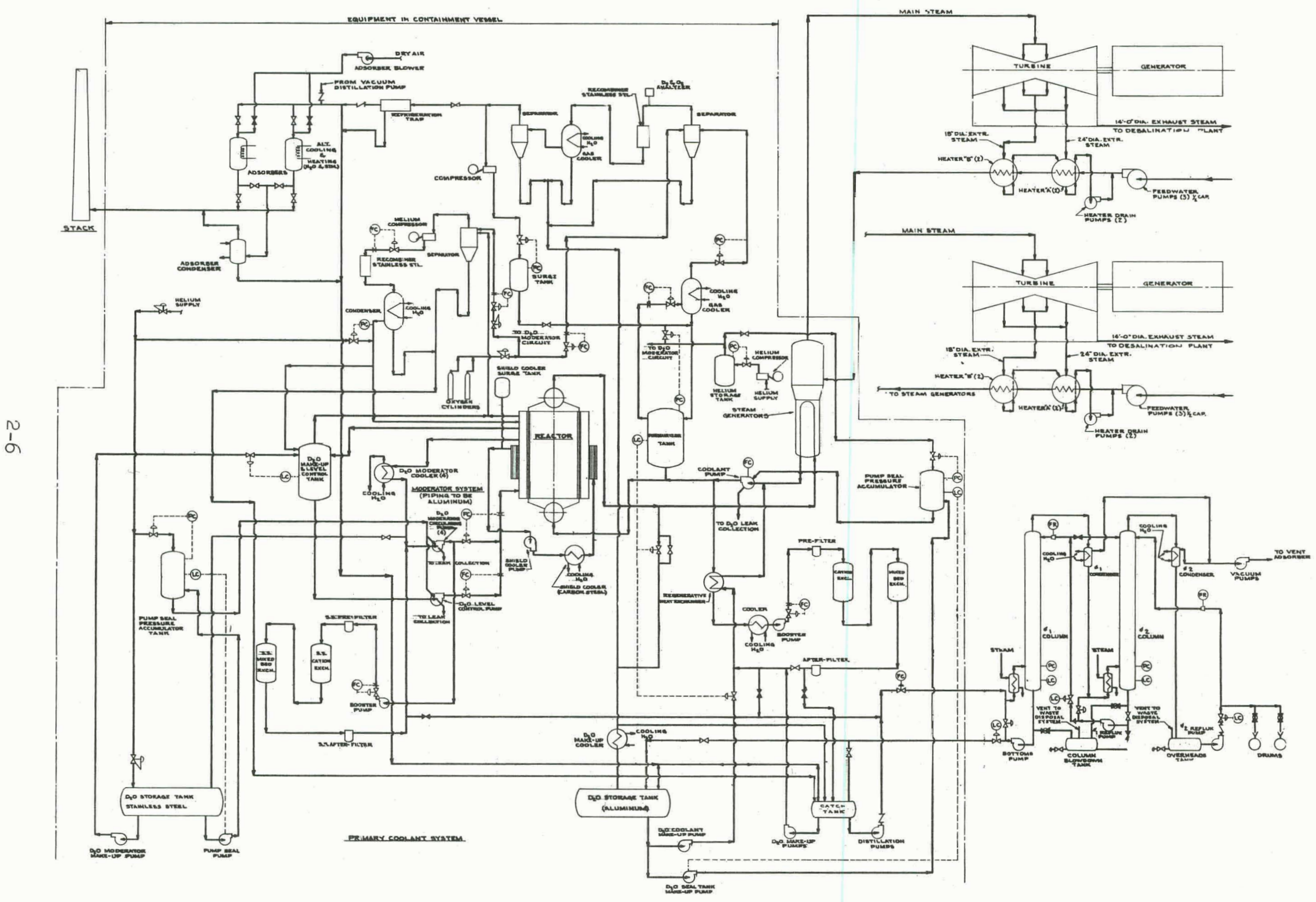

FIG. 2.4 FLOW DIAGRAM FOR $3500-M W *$ LIQUID-D $20-$ COOLED PLANT (7) 
The primary system pressure is $1700 \mathrm{psi}$ and the saturation temperature is $320^{\circ} \mathrm{C}$. This pressure is specified so that the surface temperature is limited to about $330^{\circ} \mathrm{C}$ by surface boiling. The average coolant effluent temperature is $304^{\circ} \mathrm{C}$, but with the proposed charging scheme in which one-third of the fuel is replaced at each shutdown, the effluent from the hottest assembly is about $310^{\circ} \mathrm{C}$. Allowing for hot spot factors, it is expected that some boiling will occur at the outlet of the hottest subchannels. The coolant temperature rise is $40^{\circ} \mathrm{C}$ at 350,000 gpm.

The maximum heat rating of an average exposure element in the flat zone is 38 watts $/ \mathrm{cm}\left(1800^{\circ} \mathrm{C}\right)$, and the maximum heat flux is $467,000 \mathrm{pcu} /(\mathrm{hr})\left(\mathrm{ft}^{2}\right)$. Initial heat ratings of freshly charged elements may be as high as 44 watts $/ \mathrm{cm}\left(2000^{\circ} \mathrm{C}\right.$ ) and heat fluxes may reach 540,000 pcu/ $(\mathrm{hr})\left(\mathrm{ft}^{2}\right)$ under the proposed charging scheme.

Steam pressure at the turbine throttle valve is 650 psia. As a dual-purpose plant, the turbine exhaust pressure is $45 \mathrm{psia}$ and the plant produces $550 \mathrm{MW}$ of electricity and $240 \times 10^{9}$ Btu/day of steam at $274^{\circ} \mathrm{F}$. As a single-purpose plant, with a condenser at 1.5 inches of mercury absolute pressure, about 1000 MW of electricity is produced.

\subsection{TURBINE PLANT}

The turbine plant contains two 1800-rpm, noncondensing, tandem compound, double flow turbines. These units are designed to operate with 650 psia saturated throttle steam and to exhaust steam at 45 psia. Each turbine has two stages of extraction to provide steam for feedwater heating. The turbine exhaust steam is then piped directly to the desalination plant. Condensate is returned to the turbine plant at $274^{\circ} \mathrm{F}$ and is heated to a final temperature of $388^{\circ} \mathrm{F}$ by the two stages of feedwater heaters. A more detalled description of the turbine plant and a detailed breakdown of the turbine plant costs are provided in Reference 7 . The turbine building arrangement drawings, prepared by Sargent and Lundy, are reproduced in Figures 2.5, 2.6, and 2.7. 


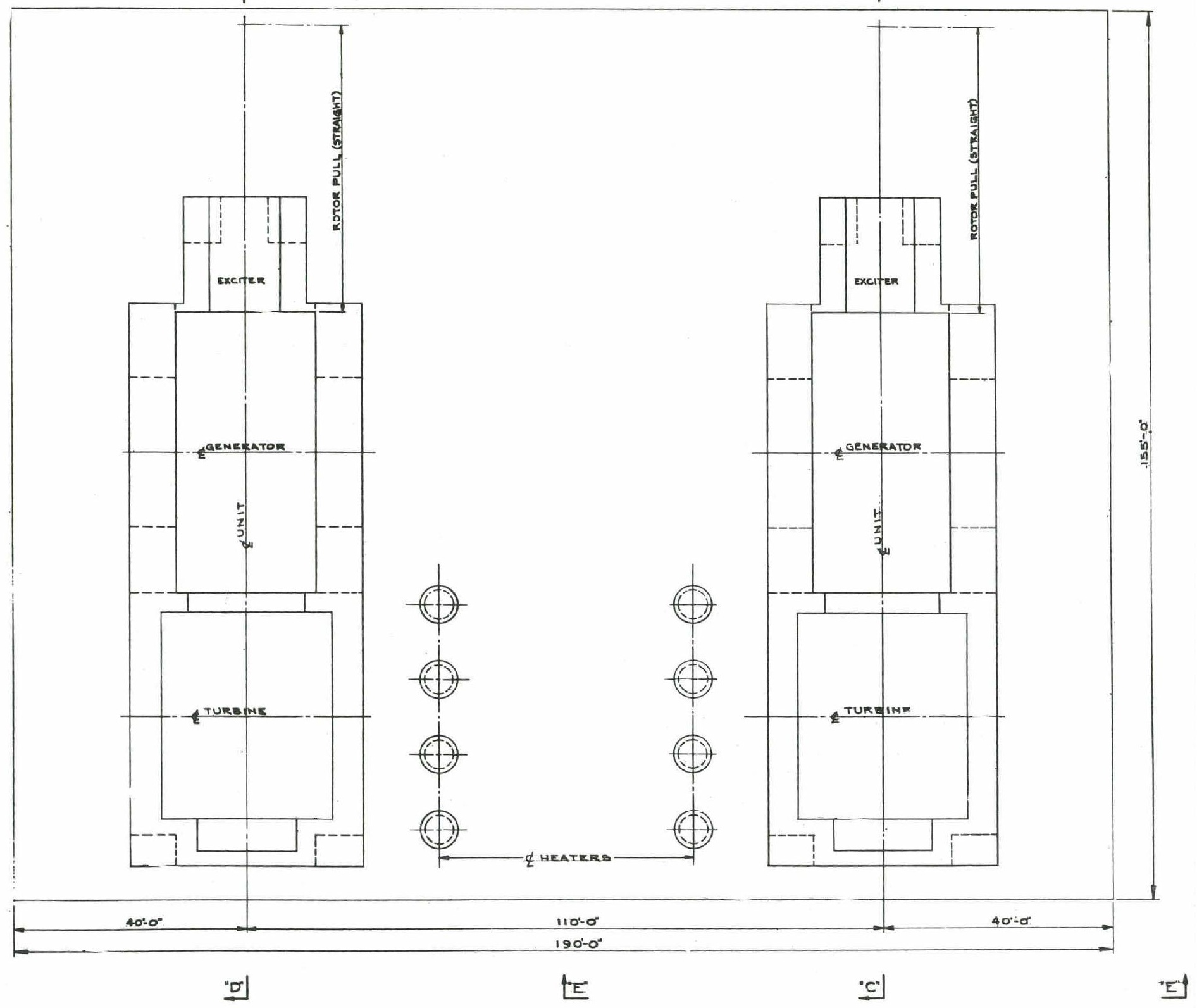

$5 \quad 10 \quad 15 \quad 20 \quad 28$

FIG. 2.5 GENERAL ARRANGEMENT PLAN "A-A" - TURBINE BUILDING $3500-M W_{+}$LIQUID-D 2 O-COOLED PLANT 


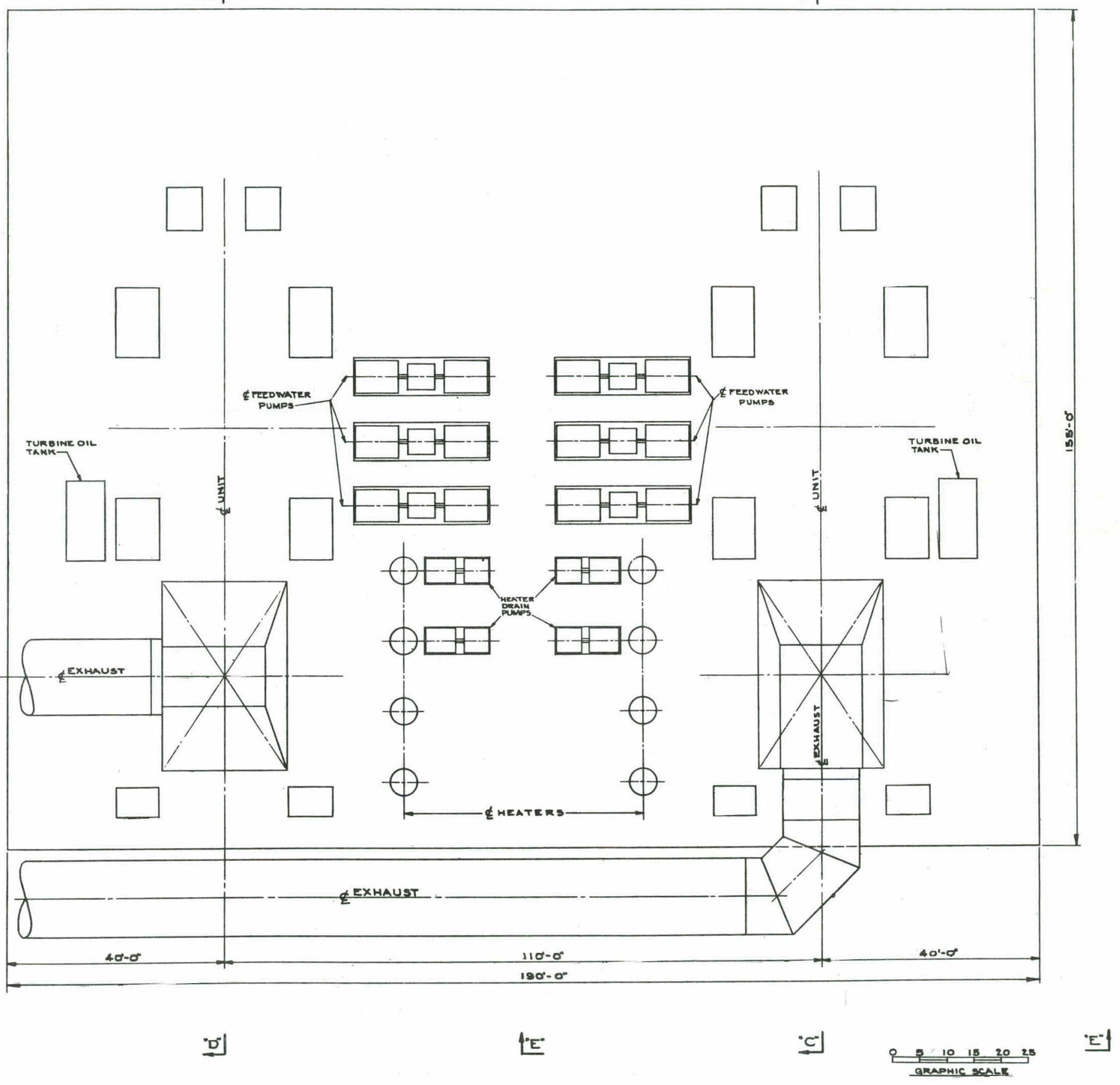

PLAN "B-B

FIG. 2.6 GENERAL ARRANGEMENT PLAN "B-B" - TURBINE BUILDING 3500-MW+ L.IQUID-D, O-COOLED PLANT 

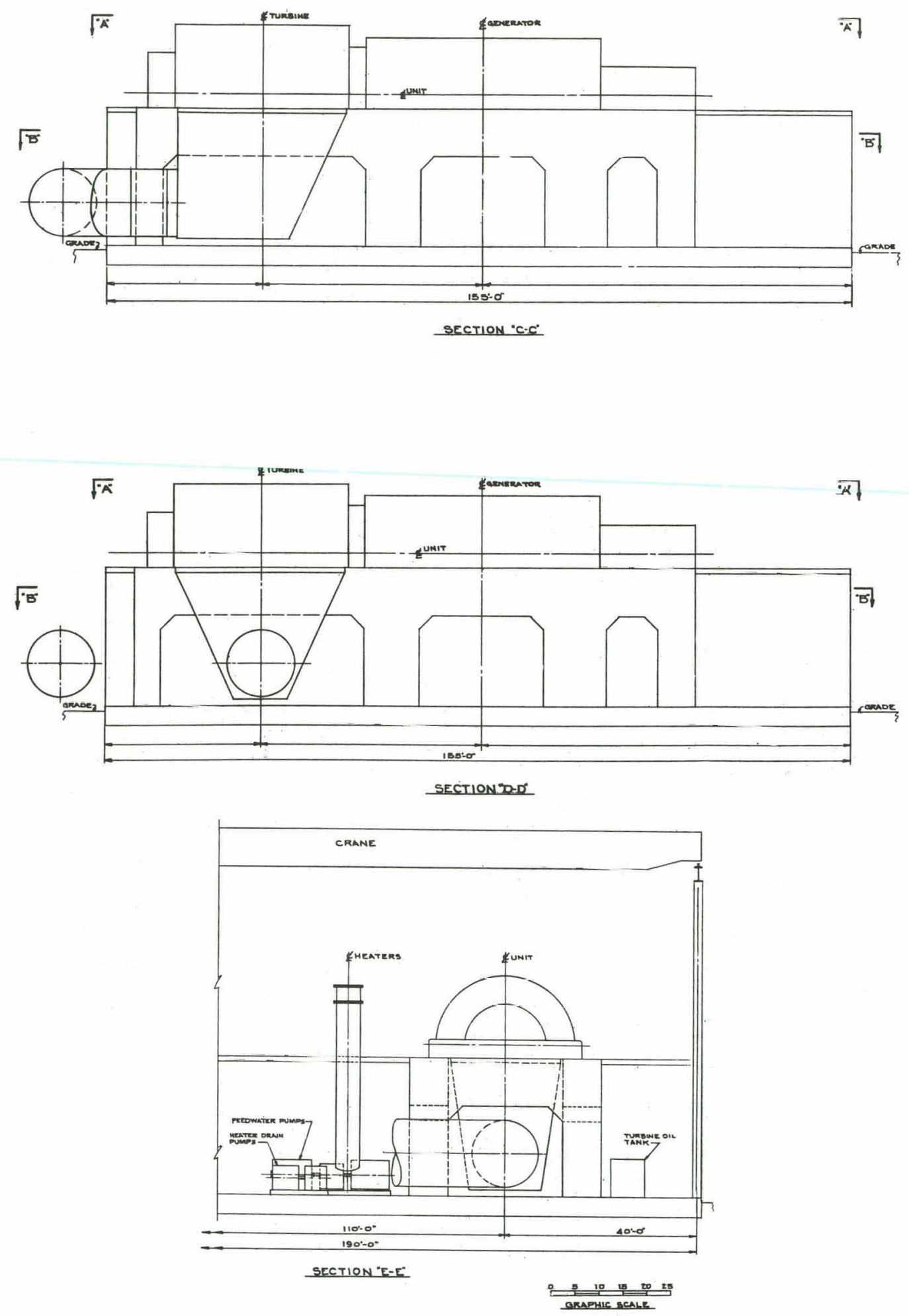

FIG. 2.7 GENERAL ARRANGEMENT SECTIONS - TURBINE BUILDING $3500-M W_{+}$LIQUID-D 2 O-COOLED PLANT 


\subsection{CONTAINMENT}

A conventional low-leakage steel shell is provided to contain the steam and fission products released in the maximum credible accident, which is a rupture of the primary piping. For this reactor the required containment volume is determined by the equilibrium pressure after the accident rather than by the equipment size.

The general arrangement drawings of the containment building were prepared by Sargent and Lundy and are shown in Figures 2.8, 2.9, and 2.10.

\subsection{COOLANT TREATMENT}

The coolant and moderator are maintained at high $\mathrm{pH}$ and low oxygen content to minimize corrosion of the carbon steel components. They are purified by running continuous sidestreams through deionizers and distillation columns. An annual leakage of $2 \%$ of all the $\mathrm{D}_{2} \mathrm{O}$ in the system is assumed.

\subsection{REACTOR PLANT AUXILIARY SYSTEMS}

The reactor plant auxiliary systems consist of:

Waste Disposal System

$\mathrm{D}_{2} \mathrm{O}$ Distillation System

Fuel Handling System

Coolant storage and Makeup Systems

Moderator Storage and Makeup Systems

Off-Gas System

Liquid Poison System

Moderator Cooling System

Coolant and Moderator Purification Systems

The design and cost estimates for these systems were made by Sargent and Lundy and are described in Reference 7 . 


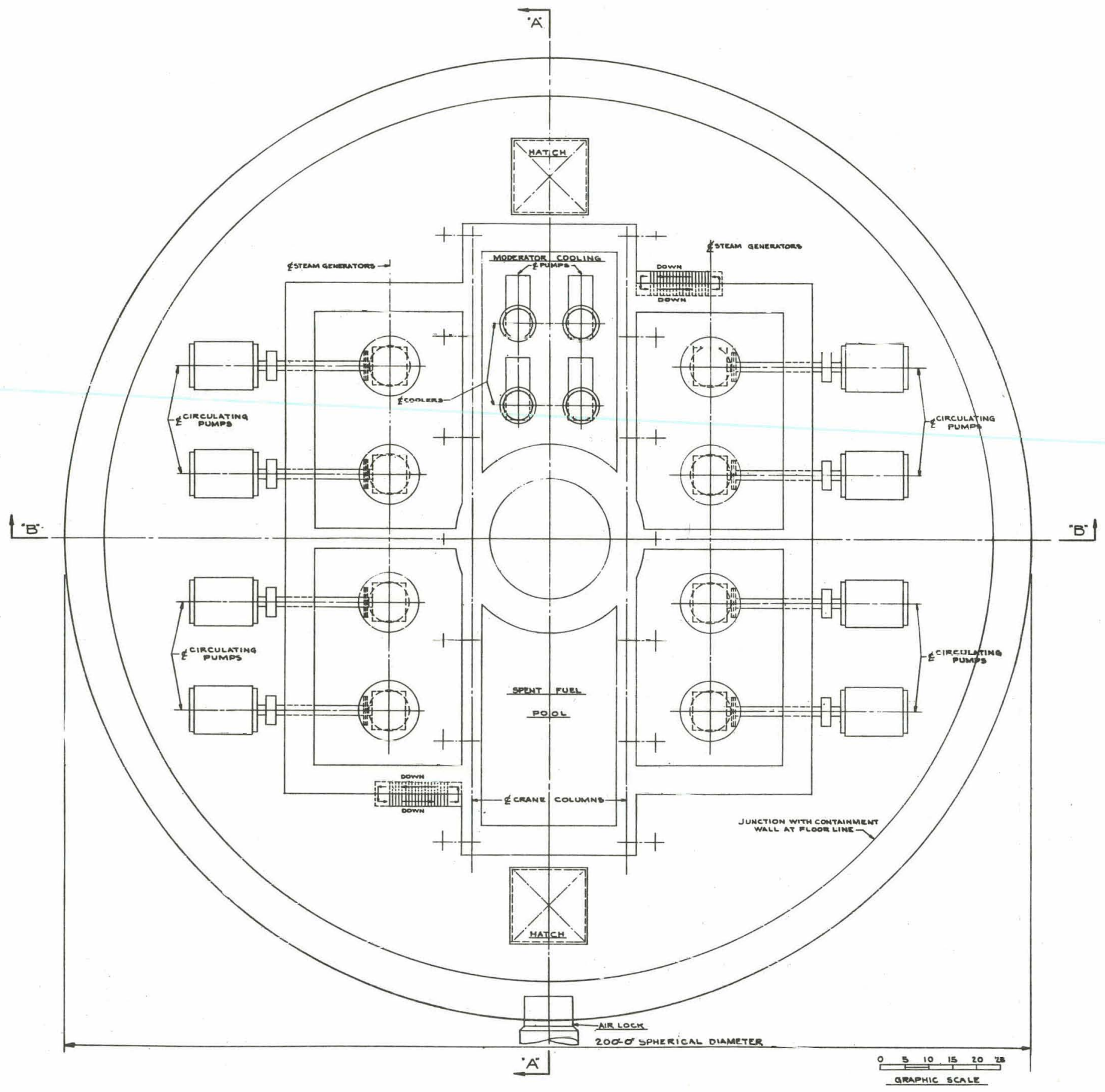

FIG. 2.8 GENERAL ARRANGEMENT PLAN - REACTOR BUILDING $3500-M W_{+}$LIQUID-D 2 O-COOLED PLANT 


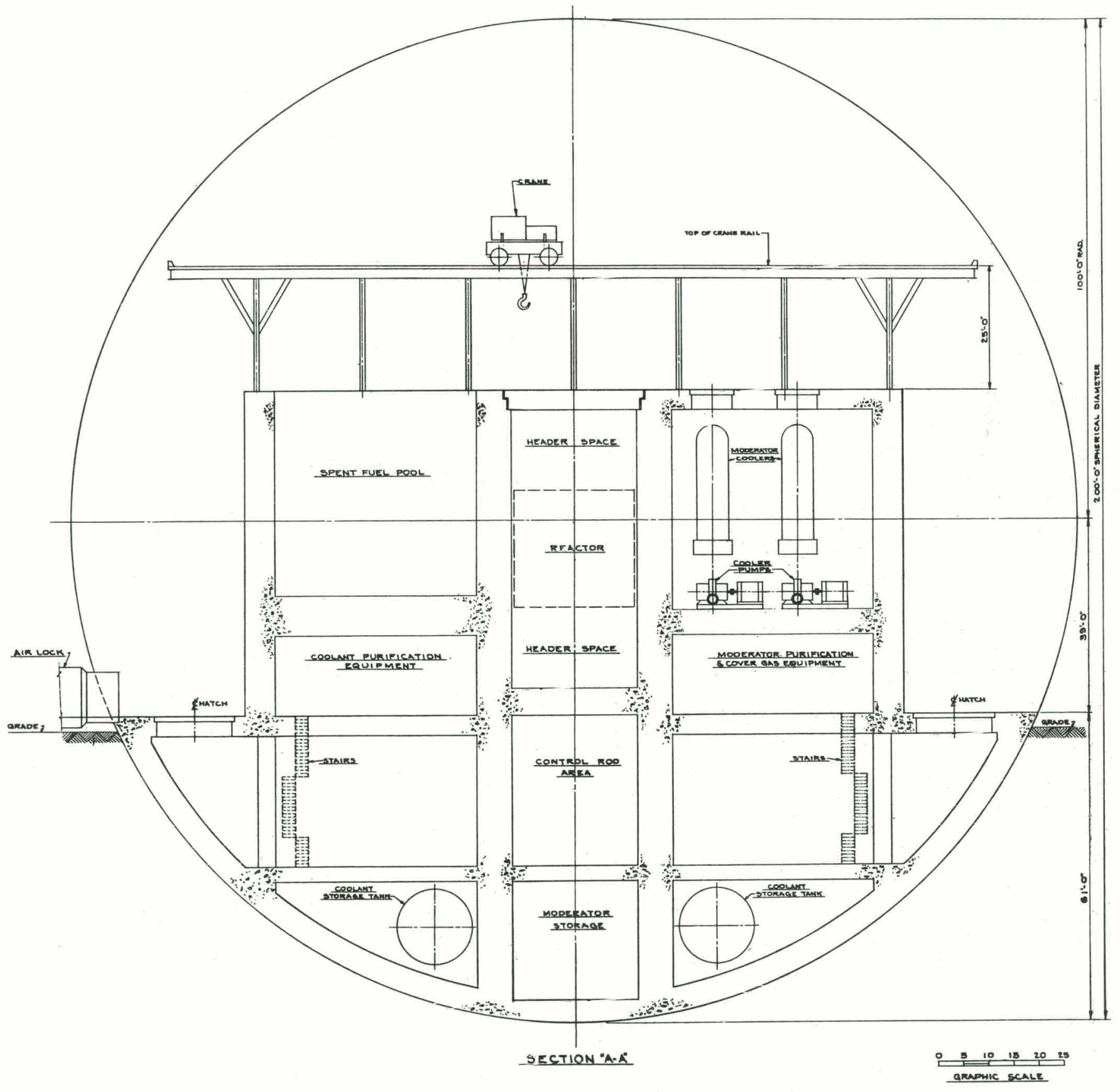

FIG. 2.9 GENERAL CROSS SECTION "A-A" - REACTOR BUILDING 3500-MW + LIQUID-D 2 O-COOLED PLANT 


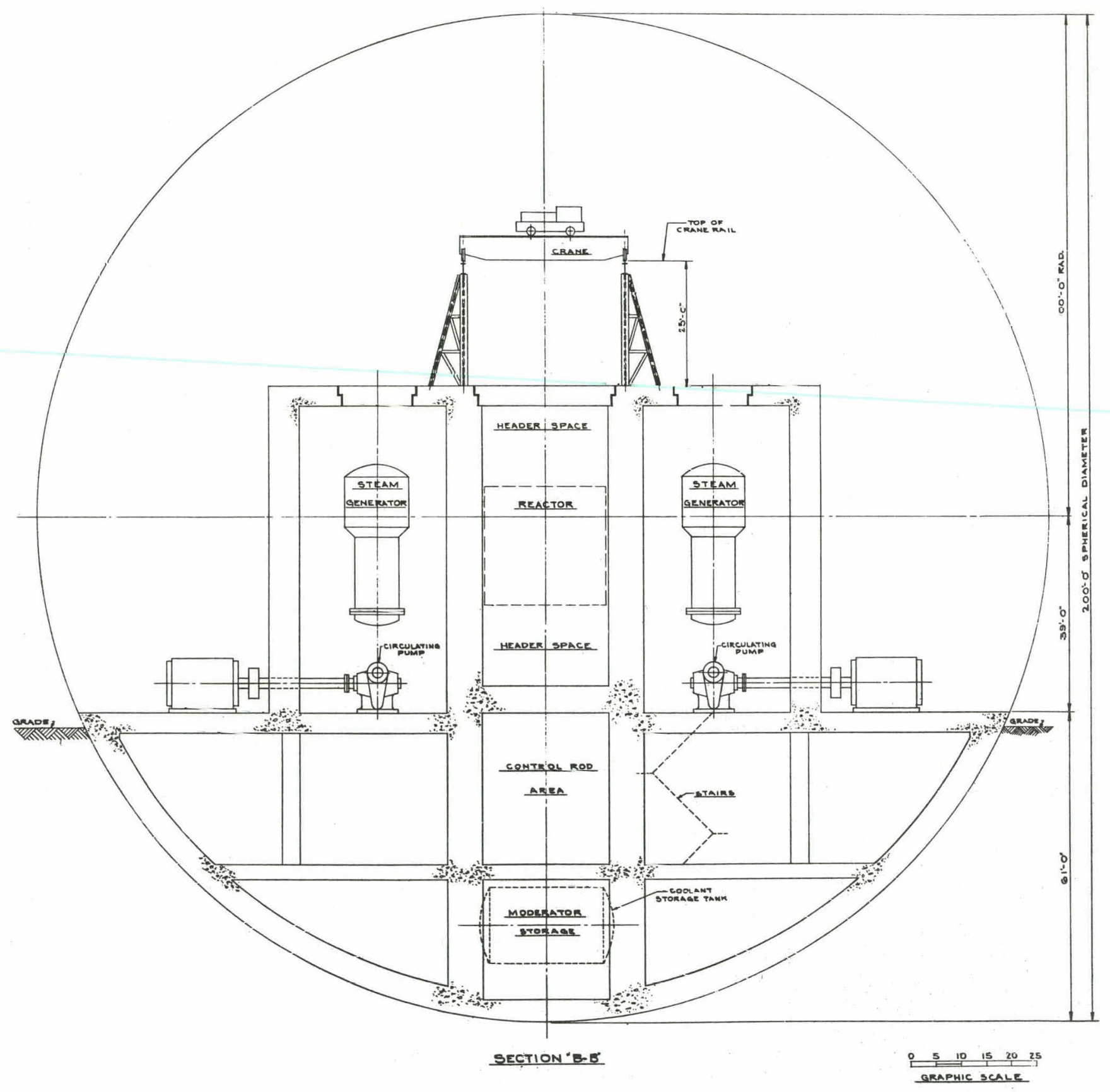

FIG. 2.10 GENERAL CROSS SECTION "B-B" - REACTOR BUILDING 3500-MWt LIQUID-D 2 O-COOLED PLANT 


\section{3. $8300-M W_{\dagger}$ REFERENCE DESIGN}

\subsection{CORE DESIGN}

\section{General}

Major design parameters for the organic-cooled 8300-MWt reactor are listed in Table 3.1 . This is a vertical pressure tube reactor that contains 1400 fuel assemblies. The $D_{2} O$ moderator is contained in a calandria. Complete design and preliminary cost data are given in Appendix $B$.

\section{TABLE 3.1}

Design Parameters for 8300-MWt Organic-Cooled Reactor

$\begin{array}{lc}\text { Fuel } & \text { UC tubes } \\ \text { U}^{235} \text { enrichment } & \text { Natural } \\ \text { Coolant pressure, psi } & 300 \\ \text { Core length, ft } & 20 \\ \text { Number of fuel positions } & 1400 \\ \text { Reactor power, MW to steam generators } & 8392 \\ \text { Coolant outlet temperature, }{ }^{\circ} \mathrm{C} & 380 \\ \text { Coolant inlet temperature, }{ }^{\circ} \mathrm{C} & 280 \\ \text { Power of average flat zone assembly, MWt } & 6.3 \\ \text { Maximum fuel temperature, }{ }^{\circ} \mathrm{C} & 604 \\ \text { Maximum sheath temperature, }{ }^{\circ} \mathrm{C} & 470 \\ \text { Maximum heat flux, pcu/(hr) (ft }{ }^{2} \text { ) } & 332,000 \\ \text { Average fuel exposure, MWD/tonne U } & 8500 \\ \text { Steam pressure at turbine throttle, psia } & 787 \\ \text { Steam temperature at turbine throttle, }{ }^{\circ} \mathrm{F} & 676\end{array}$

$\begin{array}{lccc} & \begin{array}{c}\text { Electricity } \\ \text { Only }\end{array} & \begin{array}{c}\text { Electricity } \\ \text { and Steam }\end{array} \\ \text { Gross electrical output, MW } & 2850 & 1330 \\ \text { Net electrical output, MW } & 2660 & 1190 \\ \text { Steam generated, } 10^{9} \mathrm{Btu} / \text { day } & - & 580 \\ \text { Steam pressure at turbine outlet } & 1.5^{\prime \prime} \mathrm{Hg} & 95 \mathrm{psia} \\ \text { Steam temperature at turbine outlet, }{ }^{\circ} & 92 & 324\end{array}$




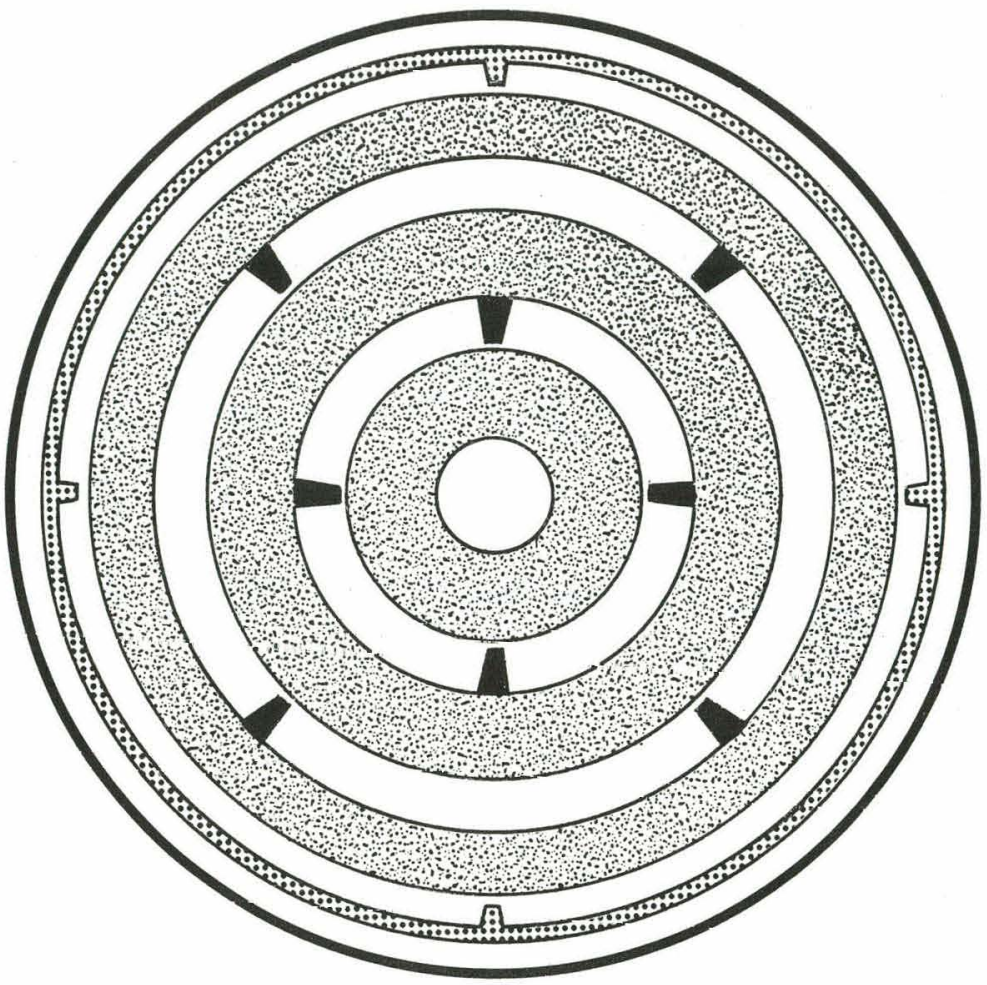

Full Scale

Zircaloy Calandria Tube
$\ldots$ Zr $-2.5 \%$ Nb Pressure Tube
Cast UC Fuel Tubes Clad
with $0.020^{\prime \prime}$ of SAP

FIG. 3.1 FUEL ASSEMBLY FOR ORGANIC-COOLED REACTOR

Fuel Assembly and Pressure Tube

The organic-cooled fuel assembly (Figure 3.1) consists of three concentric tubes of natural uranium carbide. Each assembly contains 500 pounds of UC. The individual tubes, each 10 feet long, are made by enclosing cast UC cores in extruded sheaths of Siritered Aluminum Product (SAP) that have a 0.020 -inch wall. The inner sheaths of the two outer fuel tubes are ribbed extrusions. Cross-section dimensions of the fuel tubes are listed below.

$\begin{array}{ccc}\text { Fuel Tube No. } & \text { Clad OD, in. } & \text { Clad ID, in. } \\ 1 & 3.20 & 2.66 \\ 2 & 2.24 & 1.56 \\ 3 & 1.13 & 0.42\end{array}$


The eventual optimum fuel assembly may have a central rod instead of the smaller diameter tube.

The pressure tubes are cold-worked $\mathrm{Zr}-2.5 \% \mathrm{Nb}$ tubes to which stainless steel end fittings are attached by tandemextruded joints. The pressure tube is lined with a diffusion barrier to prevent hydriding of the zirconium alloy. A 0.120inch annulus of inert gas is provided between the pressure tube and calandria tube to minimize heat losses to the moderator and contamination of the coolant or moderator.

\section{Lattice Design}

Figure 3.2 shows one quadrant of the 8300-MWt reactor core. The core contains 1400 fuel assemblies on a 9-inch square pitch, is 20 feet long and 32 feet in diameter. A $20-1$ nch radial reflector and 24 -inch axial reflectors of $\mathrm{D}_{2} \mathrm{O}$ are provided. Reactor control is provided by 89 control positions, each containing $2-1 / 2$ conventional control rods; 80 safety rods occupy interstitial positions.

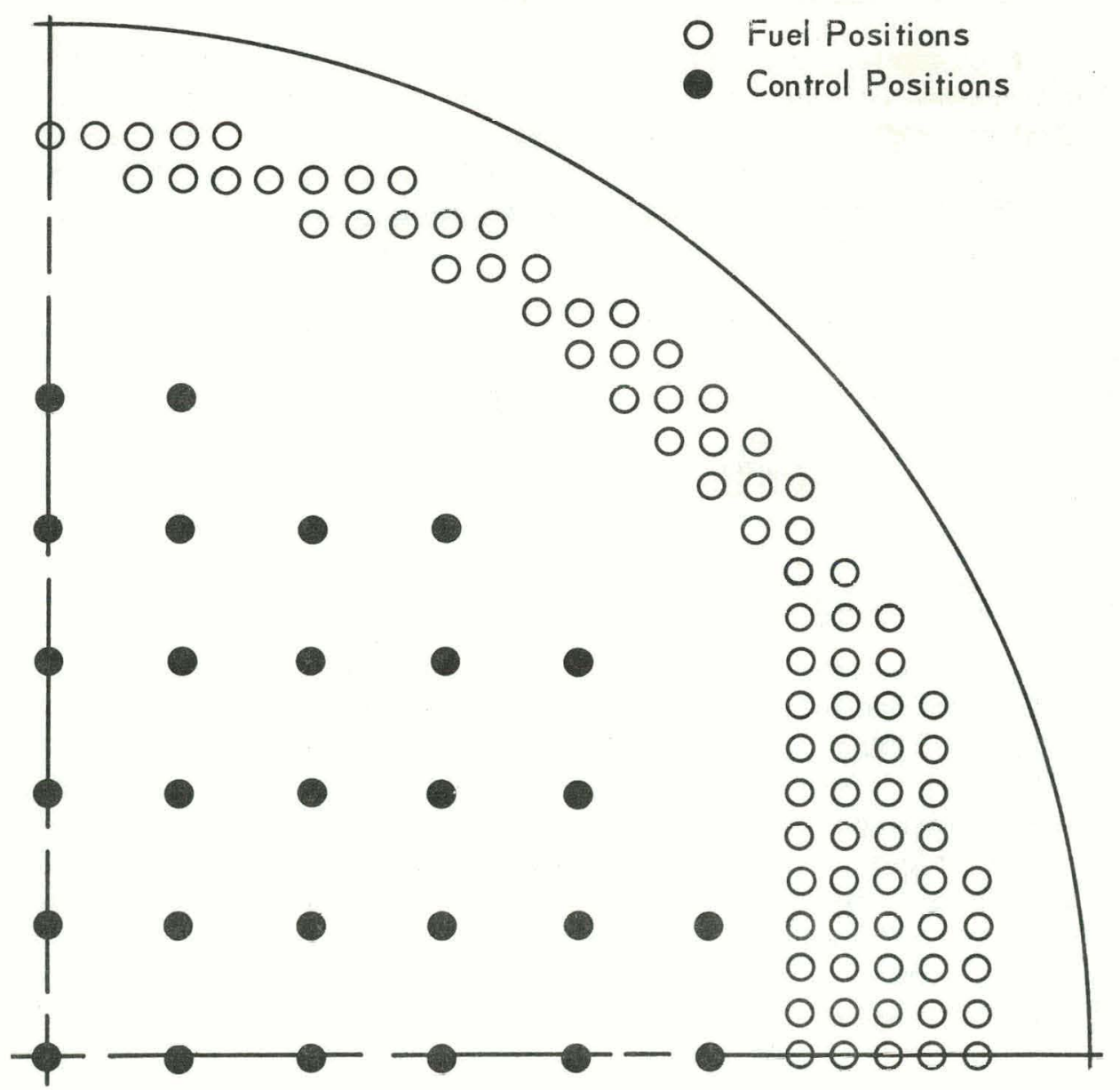

FIG. 3.2 CORE LAYOUT FOR 8300-MW† ORGANIC-COOLED REACTOR 


\section{Fuel Cycle}

Fuel is replaced a full position at a time by an on-line charging machine. The $\$ 8,000,000$ allowed for this item in the cost table (Appendix B) includes two complete machines (one spare) and all the equipment required to handle, store, and cool the fuel until it can be placed in the storage basin. The average exposure of the fuel with natural uranium is 8500 MWD/tonne U (9800 in flat zone and 7300 in buckled zone).

\subsection{REACTOR TANK AND SHIELD DESIGN}

The $\mathrm{D}_{2} \mathrm{O}$ moderator is contained in a calandria consisting of alumlium tubes, time sheets, and shell. The axial and radial thermal shields consist of armular carbor steel tanles that contain carbon steel plates cooled by $\mathrm{H}_{2} \mathrm{O}$. An annual leakage of $0.5 \%$ of all the $\mathrm{D}_{2} \mathrm{O}$ in the system is assumed.

\subsection{HYDRAULICS AND HEAT TRANSFER}

A process flow diagram of the plant is shown in Figure 3.3 . The primary coolant system consists of eight loops, each containing a pump, two steam generators, an economizer heat exchanger, and a superheater. Coolant is distributed to the pressure tubes through upper and lower plenums. The loop piping and equipment are constructed of carbon steel.

The primary system pressure is $300 \mathrm{psi}$, and the organic inlet and outlet tempcratures are 280 and $380^{\circ} \mathrm{C}$, respectively. The fuel surface temperature is limited to $470^{\circ} \mathrm{C}$. The maximum fuel temperature is $604^{\circ} \mathrm{C}$ and the maximum heat flux is $332,000 \mathrm{pcu} /(\mathrm{hr})\left(\mathrm{ft} \mathrm{t}^{2}\right)$.

\subsection{TURBINE PLANT}

The secondary steam is first used in the noncondensing turbine to produce electric power and is then conducted to the first-stage evaporator in a multiple-effect evaporator plant used to distill sea water. The turbine plant contains three tandem compound, four-flow, 1800-rpm turbines, operating at an exhaust pressure of $95 \mathrm{psia}$. The throttle steam conditions were $787 \mathrm{psi}$ and $670^{\circ} \mathrm{F}$. Each turbine unit has two stages of extraction for feedwater heating. The steam flow to each turbine is $10.5 \times 10^{6} \mathrm{lb} / \mathrm{hr}$, and the corresponding total gross electrical generation for the plant is 1330 MW. 


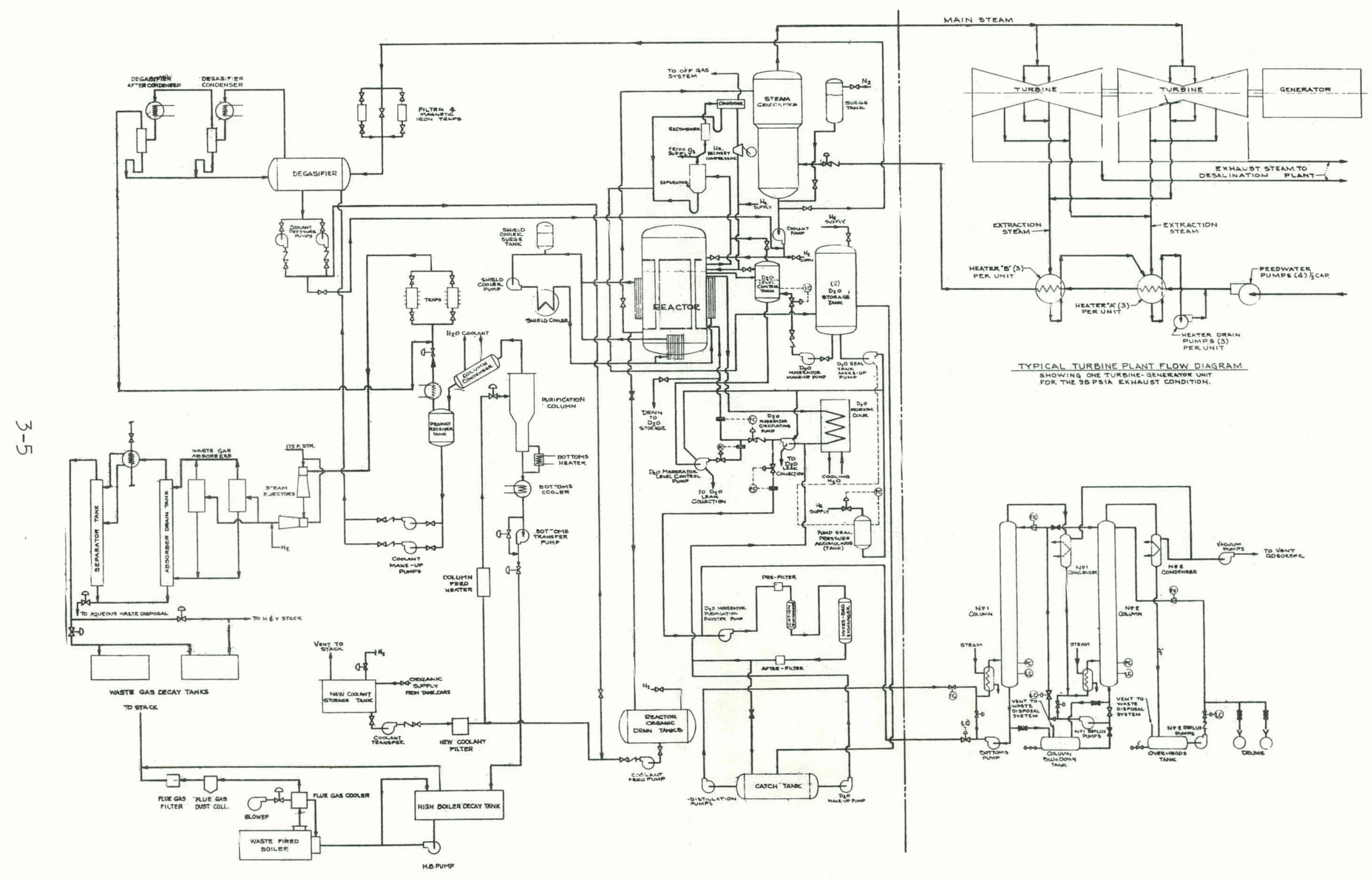

FIG. 3.3 FLOW DIAGRAM FOR 8300-MW+ ORGANIC-COOLED PLANT (7) 
The general arrangement drawings of the turbine building, prepared by Sargent and Lundy, are shown in Figure 3.4. A more detailed description and a detailed breakdown of the costs of the turbine plant have been provided by Sargent and Lundy in Reference 7 . Also included in this report are turbine plant designs in which different exhaust pressures were incorporated. Turbine plants with 45 and 182 psia exhaust pressure as well as the 95 psi pressure were included in their study.

\subsection{CONTAINMENT}

A conventional steel containment vessel is provided to minimize leakage of fission products after the maximum credible accident. A concrete shadow shield is formed inside the steel shell. For this luw prossure reactor the required building size is determined by the equipment layout, so the wall thickness is the minimum of $5 / 8$ inch and the top head thickness is the minimum of $1 / 2$ inch.

The general arrangement of the containment building is shown in Figures 3.5 and 3.6 .

\subsection{REACTOR PLANT AUXILIARY SYSTEMS}

The reactor plant auxiliary systems consist of:

Organic and Non-Organic Water Disposal Systems

$\mathrm{D}_{2} \mathrm{O}$ Distillation System

Fixel Handling System

Organic Coolant Storage and Makeup System

Moderator Storage and Makeup System

Organic and Non-Organic Off-Gas Systems

Liquid Poison System

Coolant and Moderator Purification Systems

Emergency and Shutdown Cooling System

Coolant Particulate Removal System

Steam Tracing System

The design and cost of these systems were made by Sargent and Lundy and are given in Reference 7. Also included in this reference are the design bases and a composite flow diagram for the various systems. 


\subsection{DEVELOPMENT WORK REQUIRED}

Before the construction of the 8300 -MWt reactor the following development work is required.

(1) Mechanical design and testing of the pressure tube and related liners, fittings, and seals.

(2) Testing and inspection of fuel assemblies to establish satisfactory mechanical designs and exposure life for carbide fuel.

(3) Determination of heat transfer limits for surfaces cooled by organic liquids.

(4) Prevention of fouling of heat transfer surfaces and decomposition if the cooldrll.

(5) Development of on-line refueling equipment.

In developing the design and preliminary cust estimates for this reactor it has been assumed that the above work will produce satisfactory fuel, cladding, and pressure tube designs and will verify the operating conditions on which the design is based. 

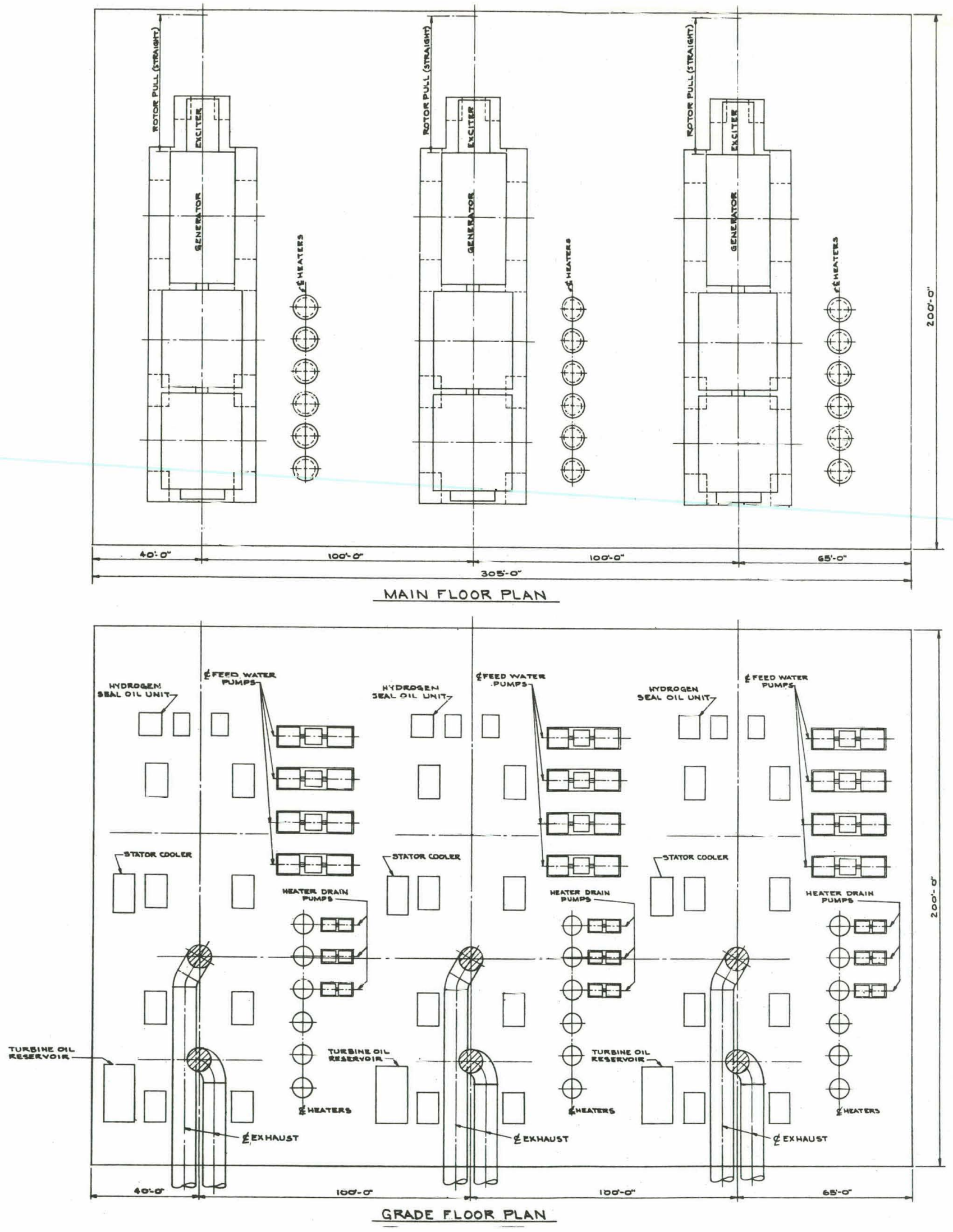

FIG. 3.4 GENERAL ARRANGEMENT PLAN - TURBINE BUILDING 8300-MW† ORGANIC-COOLED PLANT 


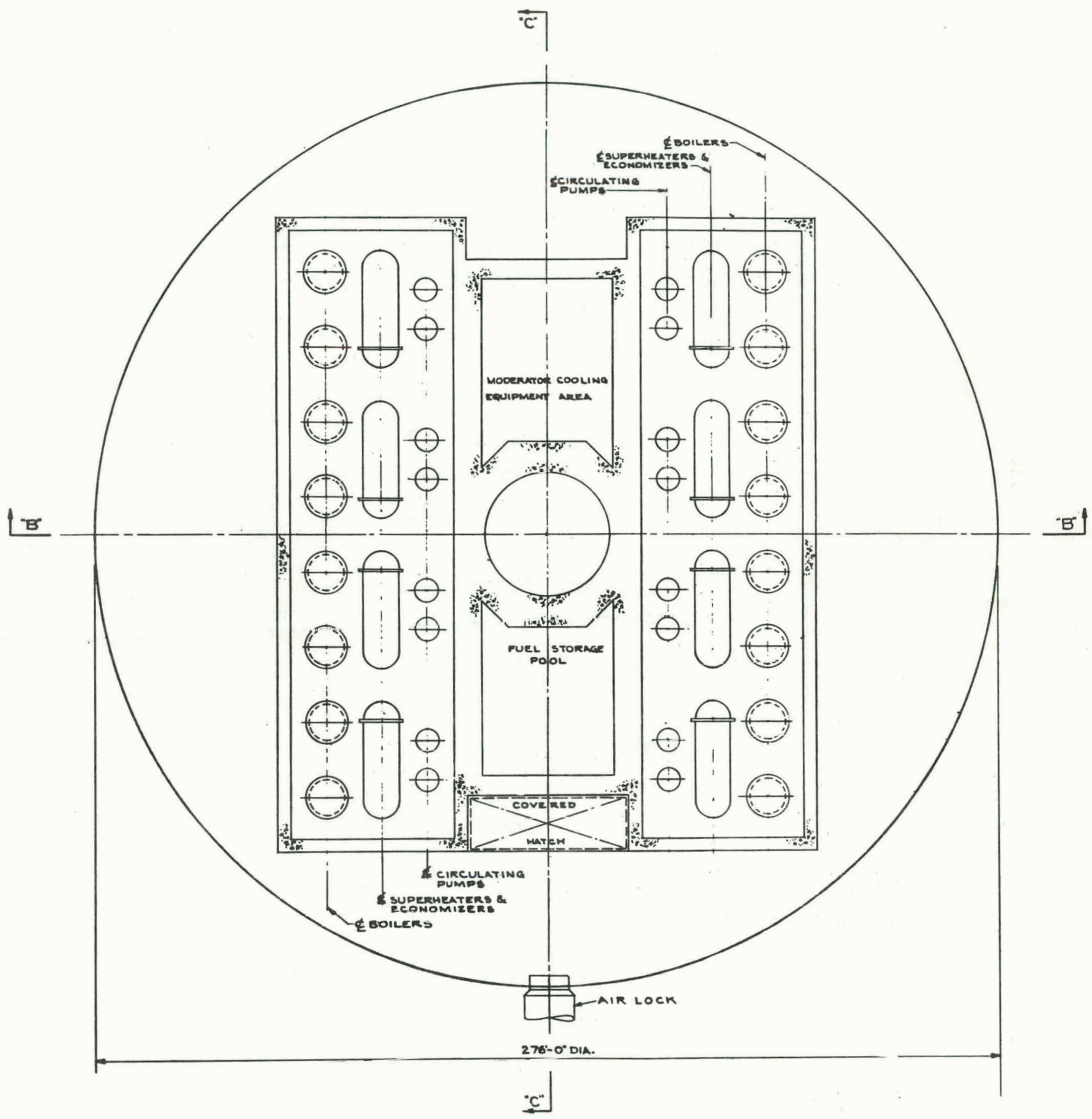

FIG. 3.5 GENERAL ARRANGEMENT PLAN "A-A" - REACTOR BUILDING $8300-M W+$ ORGANIC - COOLED PLANT 

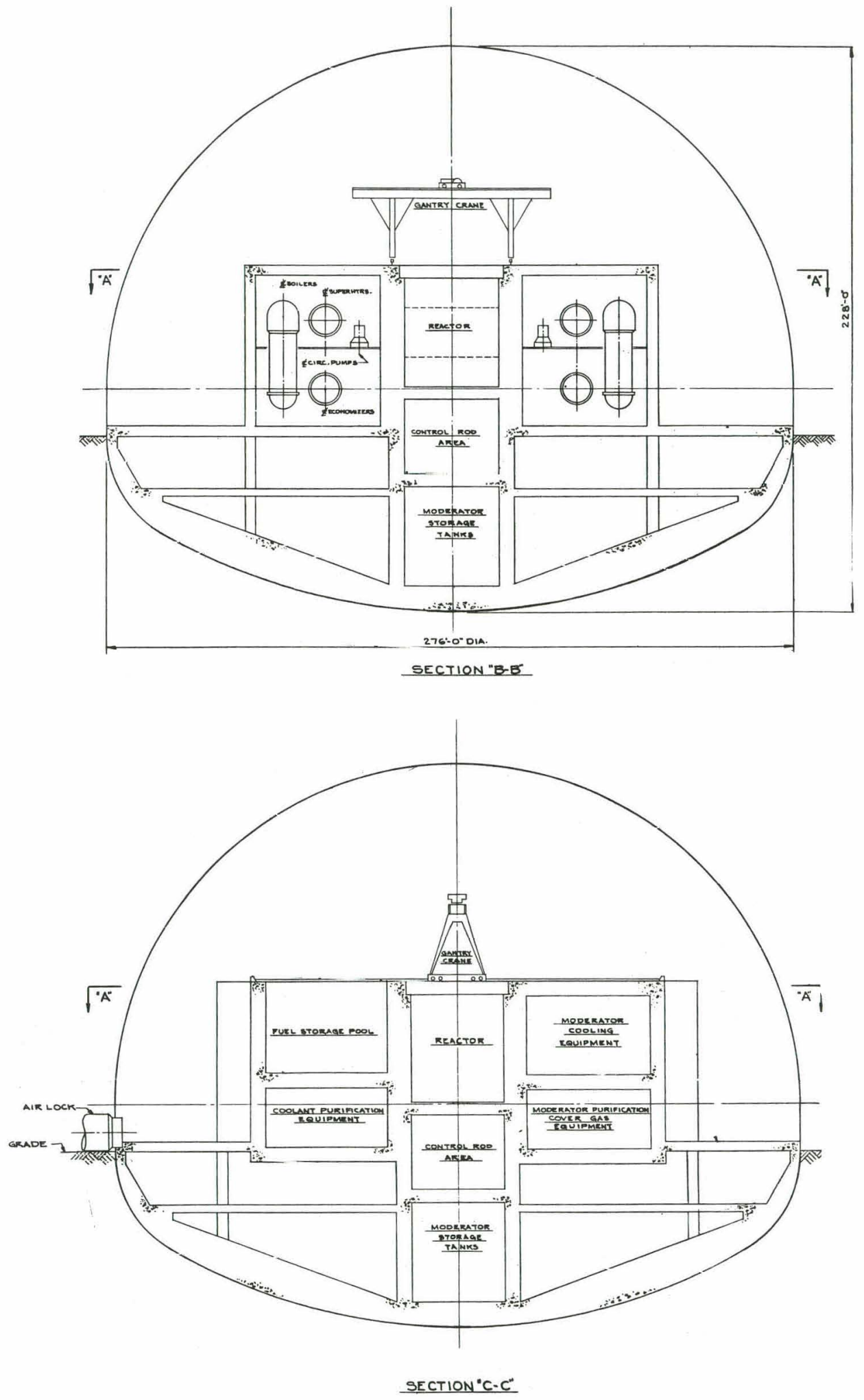

FIG. 3.6 GENERAL ARRANGEMENT SECTIONS "B-B" AND "C-C" - REACTOR BUILDING 8300-MW† ORGANIC-COOLED PLANT 


\section{OTHER $3500-M W_{\dagger}$ DESIGNS}

\subsection{ORGANIC-COOLED REACTOR}

Major design parameters of a $3500-$ MWt reactor that could serve as a prototype of the 8300-MWt organic-cooled reactor are listed in Table 4.1. This is a vertical pressure tube reactor with 640 positions on a 9-inch square pitch. The core is 20 feet long and 22 feet in diameter. The $\mathrm{D}_{2} \mathrm{O}$ moderator is contained in a calandria. Complete design data and preliminary costs are given in Appendix B.

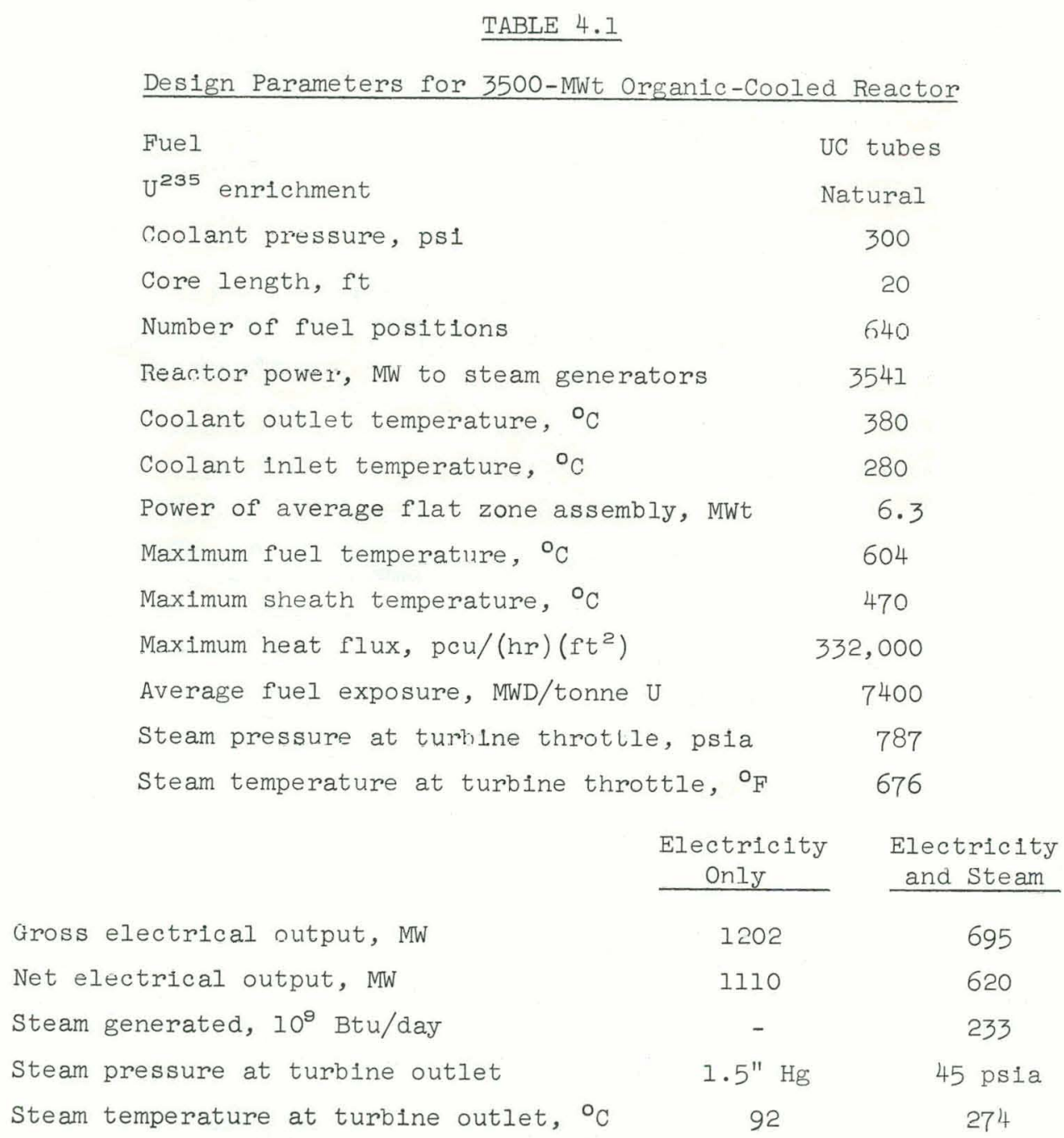

\subsection{BOILING-H $\mathrm{H}_{2} \mathrm{O}$-COOLED REACTOR}

Design parameters of a direct cycle boiling- $\mathrm{H}_{2} \mathrm{O}$-cooled reactor that can be compared with the liquid- $\mathrm{D}_{2} \mathrm{O}$-cooled, organic-cooled, and ORNL bolling-cooled reactors, are listed 
in Table 4.2. This is also a vertical pressure tube reactor in which the moderator is contained in a calandria tank. It contains 1020 fuel positions on a 9-inch square pitch, and the core is 15 feet long and 27 feet in diameter. Complete design and preliminary cost data are given in Appendix B.

TABLE 4.2

Design Parameters for 3500-MWt Boiling- $\mathrm{H}_{2} \mathrm{O}$-Cooled Reactor

\begin{tabular}{|c|c|c|}
\hline Fuel & \multicolumn{2}{|c|}{$\mathrm{UO}_{2}$ tubes } \\
\hline $\mathrm{U}^{235}$ enrichment, wt $\%$ & \multicolumn{2}{|c|}{1.19} \\
\hline Coolant pressure, psi & \multicolumn{2}{|c|}{1500} \\
\hline Core length, ft & \multicolumn{2}{|c|}{15} \\
\hline Nimher of fuel positions & \multicolumn{2}{|c|}{2020} \\
\hline Reactor power, MW to turbine & \multicolumn{2}{|c|}{3516} \\
\hline Coolant outlet temperature, ${ }^{\circ} \mathrm{C}$ & \multicolumn{2}{|c|}{315} \\
\hline Coolant inlet temperature, ${ }^{\circ} \mathrm{C}$ & \multicolumn{2}{|c|}{300} \\
\hline Power of average flat zone assembly & \multicolumn{2}{|c|}{4.0} \\
\hline Maximum fuel rating, $\int k d \theta$, watts/cn & \multicolumn{2}{|c|}{25} \\
\hline Maximum sheath temperature, ${ }^{\circ} \mathrm{C}$ & \multicolumn{2}{|c|}{325} \\
\hline Maximum heat $f l u x, p c u /(h r)\left(f t^{2}\right)$ & \multicolumn{2}{|c|}{180,000} \\
\hline Average fuel exposure, MWD/tonne U & \multicolumn{2}{|c|}{13,000} \\
\hline Steam pressure at turbine throttle, & \multicolumn{2}{|c|}{1500} \\
\hline & $\begin{array}{l}\text { Electricity } \\
\text { Only } \\
\end{array}$ & $\begin{array}{l}\text { Electricity } \\
\text { and Steam } \\
\end{array}$ \\
\hline lectrical output, MW & 1258 & 820 \\
\hline ctrical output, NW & 1175 & 750 \\
\hline enerated, $10^{9} \mathrm{Btu} / \mathrm{day}$ & - & 220 \\
\hline essure at turbine ou & $1.5^{\prime \prime} \mathrm{Hg}$ & 45 psia \\
\hline erature at turbine outlet, ${ }^{\circ} \mathrm{F}$ & 92 & 274 \\
\hline
\end{tabular}

The boiling-cooled f'uel assembly is shown in Figure 4.1. Iike the liquid-cooled design it contains three concentric tubes of mechanically compacted $\mathrm{UO}_{2}$ enriched to $1.19 \% \mathrm{U}^{235}$.

The dimensions of the fuel tubes are given below.

Fuel Tube No. Clad OD, in. Clad ID, in.

$\begin{array}{lll}1 & 4.09 & 3.28 \\ 2 & 2.88 & 1.84 \\ 3 & 1.44 & 0.42\end{array}$




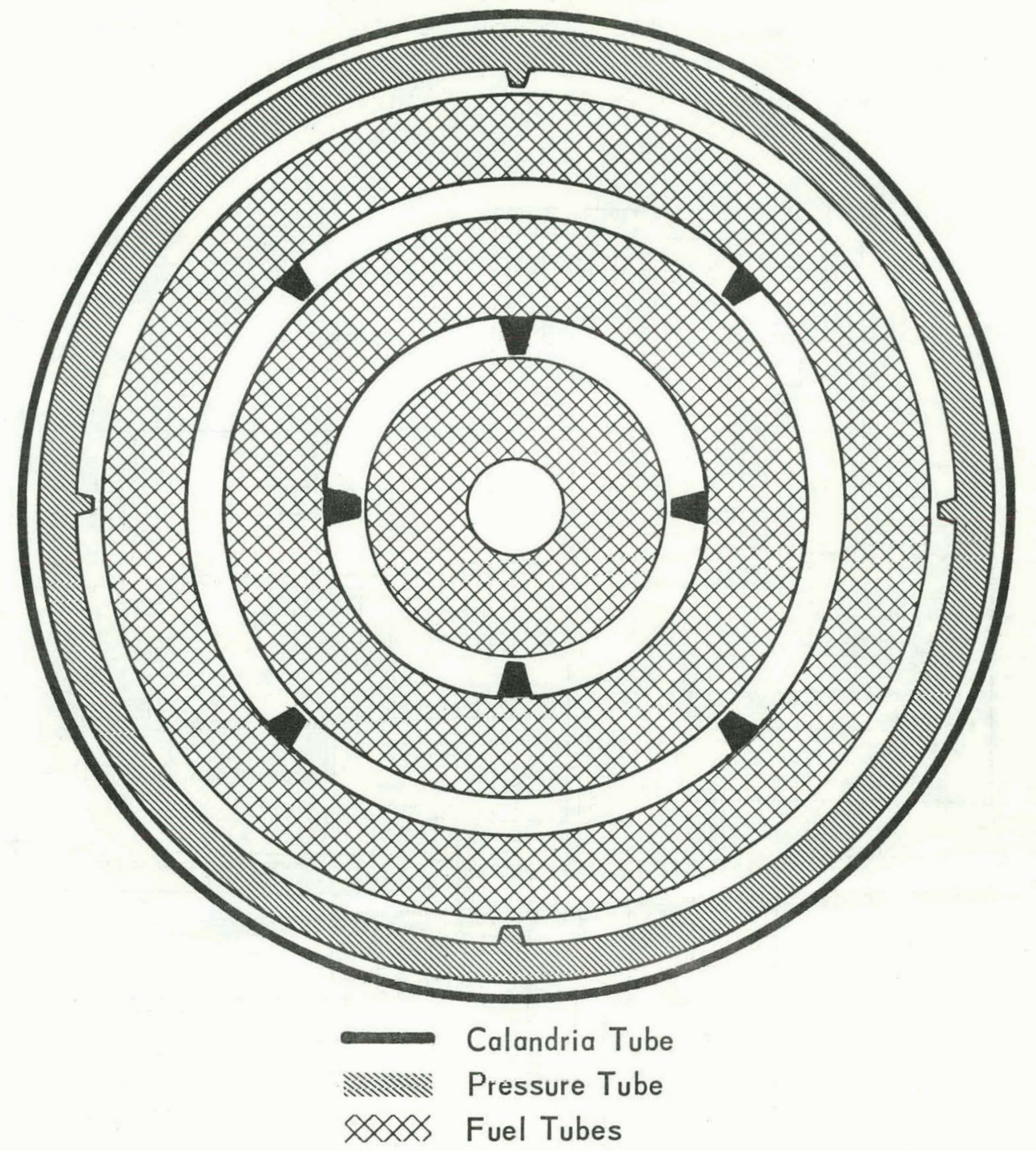

FIG. 4.1 FUEL ASSEMBLY FOR BOILING-H ${ }_{2}$ O-COOLED REACTOR

If one-third of the assemblies are replaced at each planned shutdown, the average exposure of the core is 13,000 MWD/T U (15,000 in flat zone and 12,000 in buckled zone).

The primary coolant system consists of four loops, each containing a pump and one steam separator. The $\mathrm{H}_{2} \mathrm{O}$ coolant enters the core subcooled and leaves at about 30\% quality. After the steam is separated from the two-phase mixture, it goes directly to the turbine. The separated liquid is mixed with the effluent from the regenerative feedwater heaters and recycles through the core. A process flow diagram of a bolling-cooled plant to produce electricity 


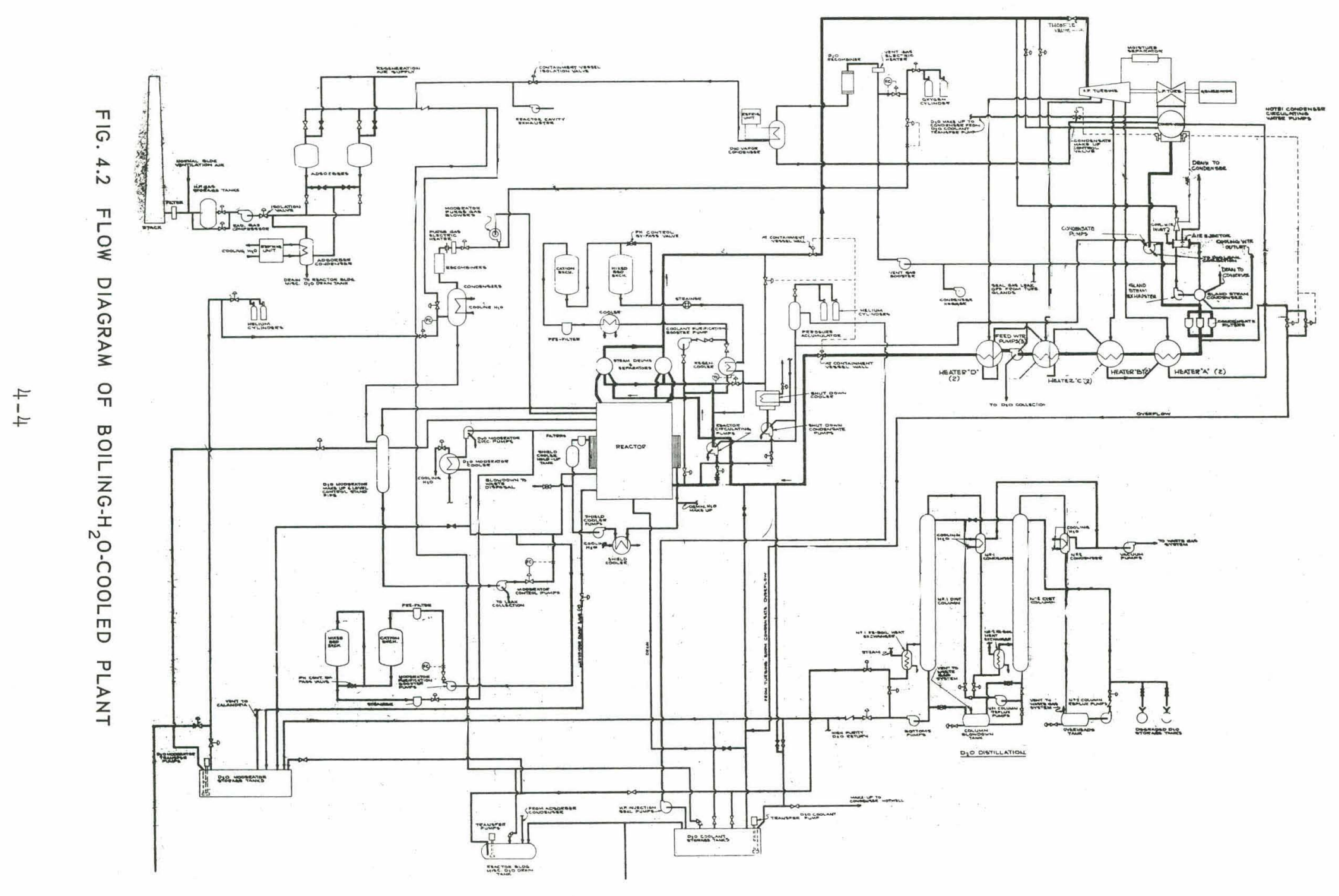

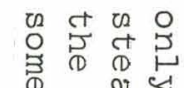

(D) ल ब

웁

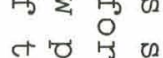

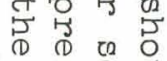

OD

苘

ڤ थ त त

ते तो

अ 090

र थ 02

त)

म

एक 雪

음

ट?

ग

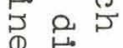

- ט

당

ब占

范

웅

눙

गे त

D

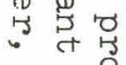

苛

吕 吕

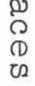


The primary system pressure is $1500 \mathrm{ps} 1$ and the saturation temperature is $315^{\circ} \mathrm{C}\left(599^{\circ} \mathrm{F}\right)$. The maximum heat flux from the fuel is $180,000 \mathrm{pcu} /(\mathrm{hr})\left(\mathrm{ft}^{2}\right)$.

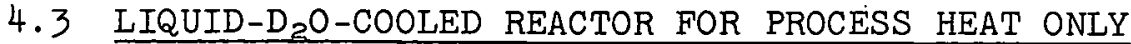

Major design parameters and capital costs of a low pressure, liquid- $\mathrm{D}_{2} \mathrm{O}$-cooled reactor are iisted in Table 4.3. This reactor is the same size as the 3500-NWt reference design, but produces steam at 45 psia in its steam generators. Savings in construction costs result from eliminating the turbine plant and reducing wall. thicknesses of the pressure tubes, primary system piping, steam generators, and containment building.

TABLE 4.3

Des1gn Parameters for 3500-MWt Process Heat Reactor

\begin{tabular}{|c|c|}
\hline Coolant & Liquid $\mathrm{D}_{2} \mathrm{O}$ \\
\hline Fuel & $\mathrm{UO}_{2}$ tubes. \\
\hline$U^{235}$ enrichment, wt $\%$ & 1.19 \\
\hline Coolant pressure, ps1 & 300 \\
\hline Core length, ft & 15 \\
\hline Number of fuel positions & 4.20 \\
\hline Reactor power, MW to steam generators & 3520 \\
\hline Coolant outlet temperature, ${ }^{\circ} \mathrm{C}$ & 190 \\
\hline Coolant inlet temperature, ${ }^{\circ} \mathrm{C}$ & 150 \\
\hline Power of average flat zone assembly, MWt & 9.8 \\
\hline Maximum fuel rating, $\int k d \theta$, watts $/ \mathrm{cm}$ & 38 \\
\hline Maximum sheath temperature, ${ }^{\circ} \mathrm{C}$ & 320 \\
\hline Maximum heat $f l u x, p c u /(h r)\left(f t^{2}\right)$ & 470,000 \\
\hline Average ruel exposure, MWD/tonne $U$ & 16,000 \\
\hline Steam pressure, psia & 45 \\
\hline Steam temperature, ${ }^{\circ} \mathrm{F}$ & 274 \\
\hline Steam generated, $10^{\circ} \mathrm{Btu} /$ day & 290 \\
\hline \multicolumn{2}{|l|}{ Capital costs, thousands of dollars } \\
\hline Reactor plant & $\$ 19,000$ \\
\hline Auxiliary facilities & 15,400 \\
\hline Total direct & 34,400 \\
\hline Indirect costs $(60 \%)$ & 20,600 \\
\hline Total & $\$ 55,000$ \\
\hline $\mathrm{D}_{2} \mathrm{O}$ inventory & $\$ 29,000$ \\
\hline
\end{tabular}


The ground rules for the entire study of the use of large reactors for sea water distillation were provided by the Office of Science and Technology Task Group under the chairmanship of Dr. Roger Revelle. The ground rules as glven in Bechtel's report( $\left.{ }^{3}\right)$ are reproduced below:

1. The Office of Science and Technology (OST) Task Group has specifled that the primary purpose of reactor station is to produce steam for a sea water distillation plant.

2. The OST Task Group specified that the electrical production is to be oblained by passing the steam from the reactor plant through a turbine using brine heaters as a condenser. The brine heaters are to heat sea water to the maximum temperature consistent with sea water evaporator technology for the time evaporator plant must be on the line. The Office of Saline Water specified these temperatures as $250^{\circ} \mathrm{F}$ for current technology stations, $300^{\circ} \mathrm{F}$ for 1975 stations, and $350^{\circ} \mathrm{F}$ for 1980 stations. For the purpose of this study, the optimum temperature difference across the brine heater can be assumed to be approximately $15^{\circ} \mathrm{F}$ for 250 and $300^{\circ} \mathrm{F}$ maximum brine temperatures and $10^{\circ} \mathrm{F}$ for $350^{\circ} \mathrm{F}$ maximum brine temperature. The final choice of brine temperature is to be governed by the temperature which produces the lowest cost water, but a maximum brine temperature of lower than $250^{\circ} \mathrm{F}$ is not to be used.

3. The reactor plant is to produce steam at conditions consistent with power reactor technology at time reactor must be committed for construction.

4. The OST Task Group specified that a typical Southern California coastal site location is to be assumed. Typical site conditions and parameters are to be selected by the Department of Interior and reviewed by the Atomic Energy Commission.

5. The following annual fixed charge rates, which the Federal Power Commission has given as representative of the two types of financling, are to be used:

Depreclating Nondepreclating

Municipal, state, or federal Investor-owned public utility
$7 \%$ $14 \%$

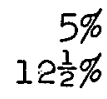


These rates include (where such 1tems are applicable) interest, administrative cost of obtaining money, return on capital, 30-year depreciation, interim replacements, property insurance, nuclear liabllity insurance, federal income taxes, state and local taxes, and grants in lieu of taxes.

6. The reactor station design is to be optimized at the munic1pal, state, or federal flxed charge rate.

7. The price of heavy water is to be assumed as $\$ 20$ per pound.

8. All costs are to be expressed in terms of 1963 dollars.

9. The OSI Task Group specifled that a combined plant factor of $80 \%$ is to be assumed. Th1s is based upon a 95\% load demand, a leactor avallab1lity nf 90\%, a turbine avallability of $97 \%$, and a brine heater avallability of $97 \%$.

10. Uraniun enrichment obtained by toll processing at $\$ 30$ separative work charge and 0.25 wt $\% U^{235}$ diffusion plant tails concentration with the Atomic Energy Commission retaining title to the tails.

11. The size stations to be.considered along with the approximate time each should be on the line, the class of reactor, the price of natural uranium, fuel fabrication cost basis, spent fuel processing cost basis, value of plutonium, and the temperature to which the sea water is to be heated is shown on Table I. Cases 1 . through 5 represent five examples of current technology. Case 6 represents an example. of 1975 reactor technology and w1ll 1llustrate the effect of varying the maximum sea water temperature. It is recognized that a $350^{\circ} \mathrm{F}$ maximum sea water temperature is. representative of 1980 evaporator technology. Cases 7,8 , and 9 represent technology in the $1980^{\prime} \mathrm{s}$ and w111 illustrate the effect of the three major fuel cycles and the effect of varying the fuel fabrication and spent fuel processing rates for each of the representative fuel cycles.

12. Fuel cycle costs for cases 1, 2, and 3 are to be based upon commerclal guarantees. Spent fuel processing costs for Cases 1, 2, and 3 are to be based upon those quoted for the Nuclear Fuel Services (NFS) plant.

13. Fuel fabrication costs for Cases 4 and 5 are to be based upon commerclal quotations assuming one fuel fabricator supplied ali fuel for the reactor. Spent fuel processing costs for cases 4 and 5 are to be based upon those quoted for the NFS plant. 
14. Fuel fabrication costs for Case 6 are to be based upon those calculated from a one-ton-per-day fabrication plant capitalizing its investment at a $15 \%$ fixed charge rate. Spent fuel processing costs for Case 6 are to be based upon those calculated from a two-ton-per-day spent fuel processing plant capitalizing its investment at a 15\% fixed charge rate. The civilian nuclear power industry has been estimated* to be discharging four tons per day of fuel in 1975. The reactor of Case 6 will discharge approximately one ton per day of spent fuel. The use of a two-ton-per-day spent fuel processing plant assumes that there will be two organizations in the spent fuel processing business in 1975 .

15. Fuel fabrication costs for Cases 7,8 , and 9 are to be based upon those calculated from 2, 5, and 10 tonper-day fabrication plants capitalizing their investment at a 15\% fixed charge rate. The reactor stations of these cases will consume approximately one ton per day of fuel. Spent fuel processing costs for cases 7,8 , and 9 are to be based upon those calculated from 4, 10, and 30 ton-per-day spent fuel processing plants capitalizing their investment at a 15\% fixed charge rate. The civilian nuclear power industry has been estimated* to be discharging 8 tons per day of spent fuel in 1980. Natural uranium prices of $\$ 6,7$, and 8 per pound of $\mathrm{U}_{3} \mathrm{O}_{8}$ and plutonium values of $\$ 9.10, \$ 9.60$, and $\$ 10.00$ per gram of plutonium $\mathrm{Pu}^{239}$ and $\mathrm{Pu}{ }^{24 I}$ in nitrate solulion are to be assumed on the basis that if the nuclear industry has grown to the point where the higher throughput rates can be used, the low cost reserves of natural uranium will be depleted. Only three sub-cases are to be calculated for each of Cases 7, 8, and 9. For example, the first subcase would use $\$ 6$ uranium, with a two-ton-per-day fabrication plant, four-ton-per-day spent fuel processing plant and a $\$ 9.10$ plutonilum credit, etc.

16. Assume cost of converting uranyl nitrate hexahydrate to uranium hexafluoride to be $\$ 5.60 / \mathrm{kg}$ of uranium.

17. Assume cost of shipping to be $\$ 12 / \mathrm{kg}$ of uranium for Cases 1, 2, and $3 ; \$ 4 / \mathrm{kg}$ for cases 4 and $5 ; \$ 2.50 / \mathrm{kg}$ for Cases 6 and 7 ; and $\$ 5 / \mathrm{kg}$ for cases 8 and 9 . This recognizes that slightly enriched high burnup fuels are more expensive to ship than less highly enriched lower burnup fuels shipped in greater volume, that natural uranium lower burnup fuels will be still less expensive, and that slightly high burnup fuels shipped in larger volume will be less expensive to ship in the future. These shipping costs include cost of shipping spent fuel to reprocessing site and cost of shipping uranium and plutonium to $A E C$ receiving plants or back to reactor stations.

\footnotetext{
*USAEC "Civilian Nuclear Power-A Report to the President-1962"
} 
18. Fuel enrichment and burnups are to be optimized for municipal, state or federal, and investor-owned public utility flxed charge rates. Fuel inventory is to be treated as a nondepreclating item. Effect of investor-owned utilities using debt financing for fuel inventory is also to be shown. The cost of debt capltal is assumed to be $7.7 \%$ per year composed of $4.5 \%$ interest, $0.8 \%$ insurance, and $2.4 \%$ taxes. Calculations are to be based upon an equilibrium fuel cycle.

19. The results of the evaluation of the nuclear energy low pressure steam supply systems are to be presented in the form of graphs showing the cost of energy avallable in the steam delivered to the evaporator plant when the byproduct power 13 credited at unit values from 1 to 6 mills per kilowatt hour. 


\section{APPENDIX B}

TABLE B. 1

Reactor Designs and Preliminary Costs

\begin{tabular}{|c|c|c|c|c|}
\hline Coozant & Liquid $\mathrm{D}_{2} \mathrm{O}$ & Bo1ling $\mathrm{H}_{2} \mathrm{O}$ & $\operatorname{Organ} 1 \mathrm{c}^{(\mathrm{a})}$ & $\operatorname{Organ} 1 c^{(a)}$ \\
\hline Power, MWt & 3500 & 3500 & 3500 & 8300 \\
\hline \multicolumn{5}{|l|}{ Fuel Des1gn } \\
\hline Fuel geometry & Tubes & Tubes & Tubes & Tubes \\
\hline Fuel matertal & $\mathrm{UO}_{2}$ & $\mathrm{UO}_{2}$ & UC & UC \\
\hline No. of fuel tubes & 3 & 3 & 3 & 3 \\
\hline Cladd1ng material & Zircaloy-2 & Zircaloy -2 & SAP & SAP \\
\hline Pressure tube material & $2 \mathrm{r}-2.5 \% \mathrm{Nb}$ & $2 r-2.5 \% \mathrm{Nb}$ & $\mathrm{Zr}-2.5 \% \mathrm{Nb}(\mathrm{b})$ & $\mathrm{Zr}-2.5 \% \mathrm{Nb}(\mathrm{b})$ \\
\hline Calandria tube material & - & Zircaloy-2 & Al um1num & Aluminum \\
\hline Pressure tube liner matelial & z1rcaloy-2 & - & - & - \\
\hline Lattice pitch, in. & 10 & 9.0 & 9.0 & 9.0 \\
\hline System pressure, psia & 1700 & 1530 & 300 & 300 \\
\hline Design pressure, psia & 2000 & 1783 & 368 & 368 \\
\hline Design temp, ${ }^{\circ} \mathrm{C}$ & 320 & 315 & 380 & 380 \\
\hline Cladding thickness, mils & 20 & 20 & 20 & 20 \\
\hline Welght of fuel, $1 \mathrm{~b} / \mathrm{ft}$ & 20 & 40 & 25 & 25 \\
\hline Inlet temp, ${ }^{\circ} \mathrm{C}$ & 264 & 300 & 280 & 280 \\
\hline Outlet temp, ${ }^{\circ} \mathrm{C}$ & 304 & 315 & 380 & 380 \\
\hline Outlet steam quality, wt $\%$ & - & 30 & - & - \\
\hline Moderator temp, ${ }^{\circ} \mathrm{C}$ & 80 & 80 & 80 & 80 \\
\hline Outer coolant channel thickness, in. & 0.20 & 0.125 & 0.125 & 0.125 \\
\hline Fuel length, in. & 180 & 180 & 240 & 240 \\
\hline Fuel density, $\mathscr{0}$ theoretical & 92 & 92 & - & - \\
\hline $\mathrm{U}^{235}$ content, $\%$ & 1.185 & 1.185 & Natural & Natural \\
\hline $\mathrm{H}_{2} \mathrm{O}$ in moderator, $\phi$ & 0.25 & 0.25 & 0.25 & 0.25 \\
\hline Calandria or liner thickness, mils & 30 & 20 & 30 & 30 \\
\hline Insulating annulus thickness, $\mathrm{mlls}$ & 60 & 60 & 120 & 120 \\
\hline Power of avg. flat zone assembly, Mw & 9.83 & 4.04 & 6.3 & 6.3 \\
\hline Power conducted to moderator, MW & 0.175 & 0.01 & - & - \\
\hline Max flow at $T_{1 n}$, gpm & 918 & 195 & 510 & 510 \\
\hline Max subohannel veloclty, $\mathrm{ft} / \mathrm{sec}$ & $47: 9$ & 65 & 51 & 51 \\
\hline Pressure drop, ps1 & 42.4 & 68 & 122 & $1 \ddot{2}$ \\
\hline Max surface temp, ${ }^{\circ} \mathrm{C}$ & 3.30 & 325 & $4 \% 0$ & 470 \\
\hline Max fuel temp, ${ }^{\circ} \mathrm{C}$ & 1800 & 1300 . & 604 & 604 \\
\hline $\int k \mathrm{~d} \theta$, watts $/ \mathrm{cm}$ & 38 & 25 & - & - \\
\hline Max heat flux, pcu/(hr) $\left(\mathrm{ft}^{2}\right)$ & 467,000 & 180,000 & 332,000 & 332,000 \\
\hline Min BOSF & 1.8 & 1.8 & 2.0 & 2.0 \\
\hline \multicolumn{5}{|l|}{ Hot Clean Lattice Parameters } \\
\hline $\begin{array}{l}\text { Cell } \Sigma_{a}, \mathrm{~cm}^{-1} \\
\text { Disad. factor } \times \Sigma_{f}, \mathrm{~cm}^{-1} \\
\eta \\
\epsilon \\
p \\
1 \\
k_{\infty} \\
L^{2}, \mathrm{~cm}^{2} \\
\tau, \mathrm{cm}^{2} \\
M^{2}, \mathrm{~cm}^{2} \\
D^{2}, \mathrm{~m}^{-2}\end{array}$ & $\begin{array}{r}0.00486 \\
0.102 \\
1.52 \\
1.02 \\
0.906 \\
0.957 \\
1.34 \\
182 \\
151 \\
333 \\
9.20\end{array}$ & $\begin{array}{r}0.001 \\
0.10 \\
1.30 \\
1.03 \\
0.90 \\
0.90 \\
1.23 \\
60 \\
140 \\
200 \\
11.3\end{array}$ & $\begin{array}{r}0.00506 \\
0.0818 \\
1.30 \\
1.03 \\
0.880 \\
0.931 \\
1.10 \\
165 \\
139 \\
304 \\
3.11\end{array}$ & $\begin{array}{r}0.00506 \\
0.0818 \\
1.30 \\
1.03 \\
0.880 \\
0.931 \\
1.10 \\
165 \\
139 \\
304 \\
3.11\end{array}$ \\
\hline
\end{tabular}

(a) "Santowax" $R$ - trademark or Monsanto Chem1cal Co.

(b) Pressure tube is lined with an aluminum diffuzion varrier. 
TABLE B.1 (Cont1nued)

Coolant

Power, MWt

Fuel Design (Continued)

Calandria Tube, in.

$O D$

ID

Pressure Tube, in.

OD

ID

Insulating Liner, in.

OD

ID

Fuel Tubes - Clad Diameters, in.

No. 1 nn

No. 2 OD

ID

No. 3 OD

Core Design

Thermal power, MW

Moderator power, MW

No. of fuel positions

No. of control positions

Min reactivity in control, $\%$

No. of safety positions

Core radius, in.

Flat zone radius, in.

Core length, ft

Radial reflector, in.

Axt,al. reflector, in.

Total coolant flow, gpm

No. of coolant loops

Uranium Inventory, tonnes

Avg specific power, MW/tonne

Max specific power, MW/tonne

Fuel exposure in BZ, MWD/tonne

Fuel exposure in FZ, MWD/tonne

Avg exposure, MWD/tonne

Sh1.eld Design

Shield Thickness, in.

Radial thermal

Top thermal

Bottom thermal

Radial biological

Shield Heat Load, Btu/hr

Radial thermal

Top thermal

Bottom thermal
Ifquid $D_{0} 0$.

3500

Bolling $\mathrm{H}_{2} \mathrm{O}$

Organic(a)

Organic (a)

8300

3500

3.82

4.90

3.82

3.76

4.60

4.28

4.74

4.34

3.52

3.52

3.44

$4: 16$

4.10

3.24

2.57

2.01

1.27

0.68

4.09

3.20

2. 88

1.84

1.44

0.42

3.20

2. $6 h$

2.24

1.56

1.13

0.42

3500

3500

212

140

420

1020

37

1.0

1.0

40

40

123

165

127

15

20

24

24

350,000

145,000

8

4

50.7

73

104

13,000

17,000

15,000

244

14

22

12,000

15,000

13,000

3500

141

640

37

1.0

$40^{\circ}$

132.1

71.0

20.

20.

$2.4^{\circ}$

297,000

8

145

25

48

6,700

9,000

7,400

3.20

2.66

2.24

1.56

1.13

0.42

8300

336

1400

89

1.0

80

192.6

125.5

20

20

24

704,000

8

312

27

46

7,300

9,000

8,500

11.8

7.9

9.4

9.9

31.3

15.0

17.3

17.4

31.3

15.0

17.3

17.4

114

114

114

114

$\begin{array}{cr}237,000 & 73,000 \\ - & 190,000 \\ - & 190,000\end{array}$

144,000

229, 000

816,000

816,000 
TABLE B.1 (Continued)

\section{Coolant}

Power, Mwt

Steam Generator Design

$\mathrm{D}_{2} \mathrm{O}$ velocity, ft/sec

Heat transfer area, $\mathrm{ft}^{2}$

Length of tubes, it

No. of tubes

Pressure on steam s1de, psig

Steam temp, ${ }^{\circ} \mathrm{C}$

Input power to steam generator, MW

$\mathrm{H}_{2} \mathrm{O}$ inventory, $1 \mathrm{~b}$ in 1 generator

$\mathrm{D}_{2} \mathrm{O}$ 1nventory, $1 \mathrm{~b}$ in 8 generators

Input power, MW

Organic inventory, Ib

Pressure drop, $f t$

Equiv. steam piping diameter, ft

Pressure drop in piping, psi

Superheater

No. of U-tubes

Length of U-tubes, $f t$

Heat transfer area, $\mathrm{ft}^{2}$

Organis. Inlet temp, ${ }^{\circ} \mathrm{C}$

Organic outlet temp, ${ }^{\circ} \mathrm{C}$

Steam outlet temp, ${ }^{\circ} \mathrm{C}$

Shell diameter, ft

Pressure drop, ft

cost, $\$ / f^{2}$

Botler

No, u. II-tubes

Length of U-tubes, ft

Heat transfer area, $\mathrm{ft}^{2}$

Steam pressure, psia

Steam temp, ${ }^{\circ} \mathrm{C}$

Organic outlet temp, ${ }^{\circ} \mathrm{C}$

Sheil diameter, $f t$

Pressure drop, ft

Cost, $\$ / f t^{2}$

Economizer

No. of U-tubes

Length of U-trubes, ft

Heat transfer area, $f t^{2}$

Organic outlet temp, ${ }^{\circ} \mathrm{C}$

$\mathrm{H}_{2} \mathrm{O}$ inlet temp, ${ }^{\circ} \mathrm{C}$

Shell diameter, ft

Pressure drop, ft

Cost, $\$ / \mathrm{ft}^{2}$

\begin{tabular}{|c|c|c|c|}
\hline Liquid $\mathrm{D}_{2} \mathrm{O}$ & Boll1ng $\mathrm{H}_{2} \mathrm{O}$ & Organic (a) & Organ $1 \mathrm{c}^{(\mathrm{a})}$ \\
\hline 3500 & 3500 & 3500 & 8300 \\
\hline
\end{tabular}

13.9
$350,000^{(c}$
44.4
60,100
665
260
3524

29,000

242,000

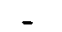

3541

8392

536,000

75

5.58

8.0

$1,310,000$

70.7

8.36

8.0

23,004

33.3

125,460

380

366.5

357.6

$7 \cdot 3$

11.7

15.00

49,658 .

45.0

365,760

806.8

270.6

291.0

6.9

47.7

20.37

27,292

23.0

102,740

280

223.3

7.3

15.5

16.19
54,956

33.8

303,800

380

366.4

358.2

11.2

12.6

14.34

122,970

44.0

885,600

806.8

270.6

291.0

10.8

43.2

19.73

68,300

22.0

?45, 900

280

223.3

11.3

14.9

15.81

(c) Includes economizer section 
TABLE B.I (Continued)

\begin{tabular}{|c|c|c|c|c|c|}
\hline Coolant & Liquid $\mathrm{D}_{2} \mathrm{O}$ & Bolling $\mathrm{H}_{2} \mathrm{O}$ & Organ1c $(a)$ & & Organic \\
\hline Power, MWt & 3500 & 3500 & 3500 & . & 8300 \\
\hline \multicolumn{6}{|l|}{ Turbine Design } \\
\hline Back pressure, psia & 45 & 45 & 45 & & 95 \\
\hline Stages of feedwater heater & 2 & 4 & 3 & & 2 \\
\hline Feedwater temp, ${ }^{\circ} \mathrm{F}$ & 388 & 509 & 434 & & 434 \\
\hline Throttle pressure, psia & 650 & 1500 & 787 & & 786.7 \\
\hline Throttle temp, ${ }^{\circ} \mathrm{F}$ & 495 & 596 & 676 & & 676.4 \\
\hline Gross turbine efficiency, & 17.6 & 23.3 & 19.6 & . & 15.9 \\
\hline Gross electric output, MW & 620 & 820 & 695 & & 1330 \\
\hline Power used by auxiliaries, MW & 70 & 70 & 75 & & 140 \\
\hline Net electrical power, Mw & 550 & 750 & 620 & & 1190 \\
\hline Reactor fission power, inw & 3713 & 3641 & 3642 & & 86,56 \\
\hline Net system efficlency, $\not$ & 14.8 & 20.6 & 17.0 & & 13.8 \\
\hline Load taoton,,$\quad$ : & 8.0 & 80 & 80 & & 80 \\
\hline Steam to evaporators, $10^{9}$ Btu/day & 240 & 220 & 233 & & 580 \\
\hline \multicolumn{6}{|l|}{ Containment Vessel Design } \\
\hline Pressure, psig & 18.5 & 18.1 & - & & - \\
\hline Radius, ft & 116 & 120 & 126 & & 145 \\
\hline Partial height, ft & 131 & 120 & 143 & & 143 \\
\hline Wall thickness, in. & 1.5 & 1.50 & 0.625 & . & 0.625 \\
\hline Top head thickness, in. & 0.75 & 0.75 & 0.50 & & 0.50 \\
\hline \multicolumn{6}{|l|}{ D.O Inventory, ih (thousands) } \\
\hline Axtal shields & 84 & - & - & & - \\
\hline Pressure tube extensions & 53 & - & - & & - \\
\hline Pigtalls & 126 & - & - & & - \\
\hline Coolant headers & 47 & - & - & & - \\
\hline Primary coolant piping & 175 & - & - & & - \\
\hline Primary coolant pumps & 26 & - & $\geq$ & & - \\
\hline Steam generator & 242 & - & - & & - \\
\hline Pressurizer vessel & 24 & - & - & & - \\
\hline Moderator HX systeill & 100 & 40 & 27.8 & & 57.0 \\
\hline Miscellaneous & 110 & 70 & 100.0 & & 140.0 \\
\hline $\begin{array}{l}\text { Core - moderator, coolant, } \\
\text { and reflector }\end{array}$ & 513 & 830 & 752.4 & & $1,454.0$ \\
\hline Total & 1,450 & 940 & 880.2 & & $1,651.0$ \\
\hline \multicolumn{6}{|l|}{ Organ1c Inventory, $1 \mathrm{~b}$ (thousands) } \\
\hline Plenum chambers & - & - & 115.5 & & 232.8 \\
\hline Pressure tube extensions & - & - & 42.1 & & 89.8 \\
\hline Primary coolant plping & - & - & 835.6 & & $1,133.4$ \\
\hline Primary coolant pumps & - & - & 19.8 & & 47.0 \\
\hline Steam generator $\quad \cdots$ & - & - & 535.7 & & $1,312.4$ \\
\hline Total & - & - & 1548.7 & & $2,815.4$ \\
\hline
\end{tabular}


TABLE B.1 (Continued)

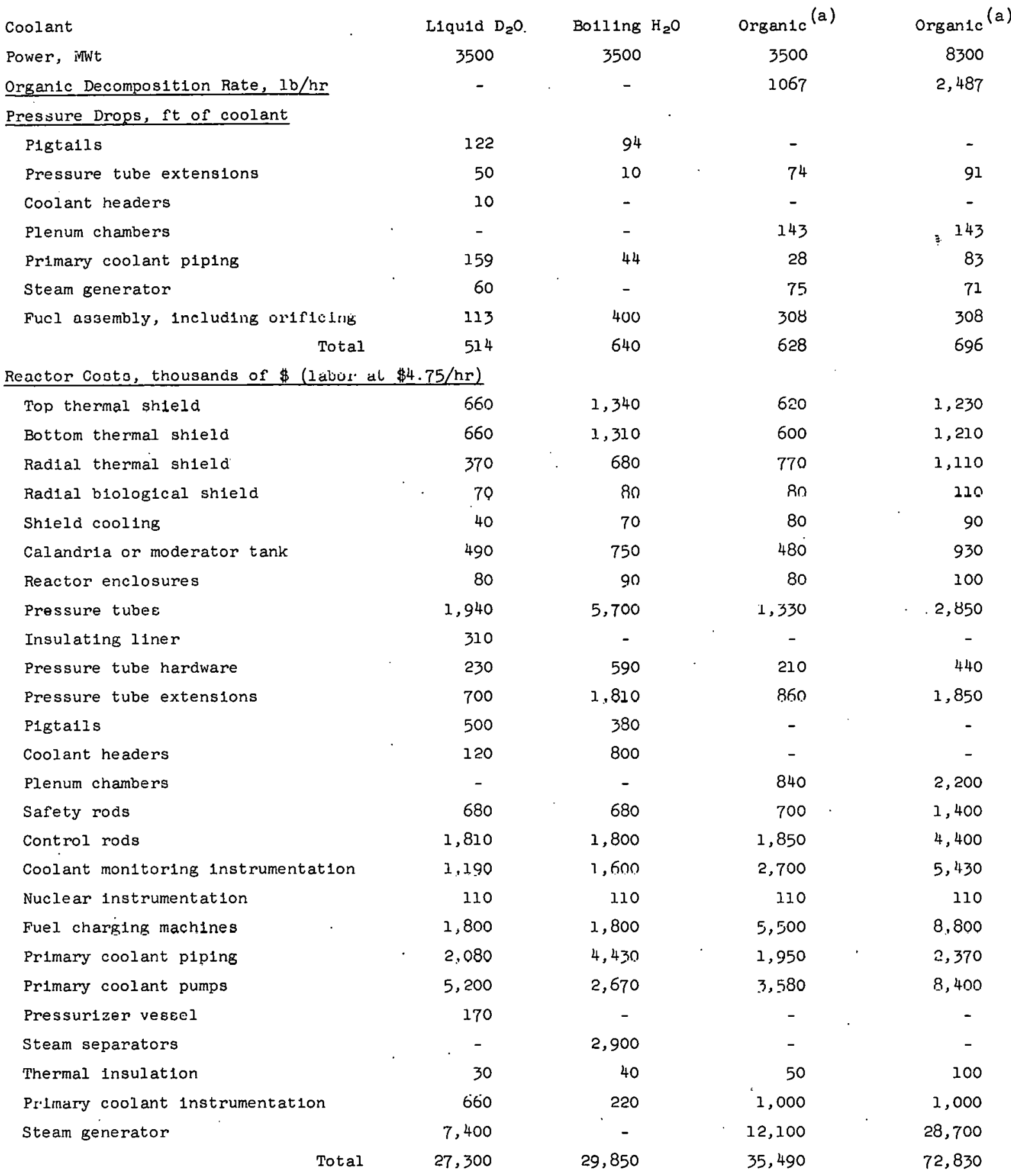


TABLE B.1. (C.ontinued)

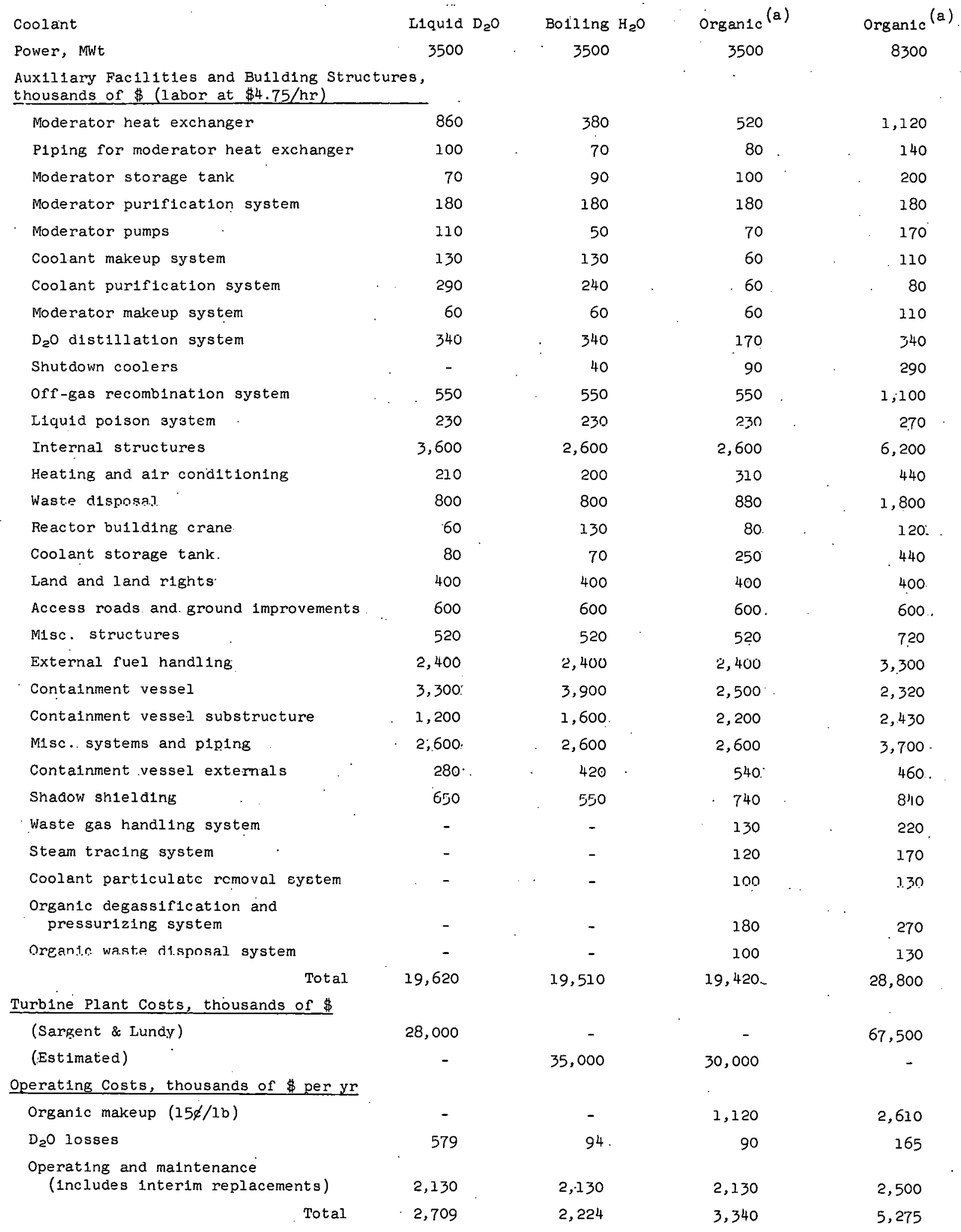


TABLE B.2

\section{Preliminary Fuel Cycle Costs}

Coolant
Power, MWt
Financing, \$/Kg U
Preparation and fabrication
Uranium depletion
Shipping
Inventory
Reprocessing
Plutonium credit
Net fuel cost
Annual fuel cost, $\$ / y r$
Average exposure, MWD/tonne $U$
Throughput, tonnes/yr

$$
\text { Liquid } \mathrm{D}_{2} \mathrm{O}
$$$$
3500
$$

$\frac{\text { Private }}{38.80} \frac{\text { Municipal }}{38.80}$

$\begin{array}{ll}38.80 & 38.80 \\ 48.91 & 48.91\end{array}$

4.00

5.07

31.30

128.08

$\frac{35.20}{92.88}$

$6,700,000$

15,000

72.1

$6,500,000$

15,000

72.1

\section{Botling $\mathrm{H}_{2} \mathrm{C}$}

3500

$\frac{\text { Private }}{38.80} \frac{\text { Municipal }}{38.80}$

$\begin{array}{ll}38.80 & 38.80 \\ 48.90 & 48.90\end{array}$

48.90
$4.00 \quad 4.00$

8.90

$\frac{-}{100.60}$

$\frac{31.30}{125.04}$

$\frac{35.20}{89.84}$

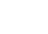

Throughpus, tonnes/yr 


\section{TABLE B.3}

Fuel Cycle Characteristics

Coolant
Power, MWt
Region
Average exposure, MWD/tonne U
Throughput, tonnes/yn
Spent fuel assay, $\mathrm{g} / \mathrm{kg} \mathrm{U}$
$\mathrm{U}^{235}$
$\mathrm{Pu}^{239}$
$\mathrm{Pu}^{240}$
$\mathrm{Pu}^{241}$
$\mathrm{Pu}$
Total $\mathrm{Pu}$

\begin{tabular}{|c|c|c|c|c|c|c|c|}
\hline \multirow{2}{*}{\multicolumn{2}{|c|}{$\begin{array}{c}\text { Liquid } \mathrm{D}_{2} \mathrm{O} \\
3500\end{array}$}} & \multirow{2}{*}{\multicolumn{2}{|c|}{$\begin{array}{c}\text { Boiling } \mathrm{H}_{2} \mathrm{O} \\
3500\end{array}$}} & \multirow{2}{*}{\multicolumn{2}{|c|}{$\begin{array}{l}\text { Organic } \\
3500\end{array}$}} & \multirow{2}{*}{\multicolumn{2}{|c|}{$\begin{array}{l}\text { Organic } \\
8300\end{array}$}} \\
\hline & & & & & & & \\
\hline Quter & Inner & Outer & Inner & Quter & Inner & Outer & Inner \\
\hline 13,000 & 17,000 & 12,000 & 15,000 & 6,700 & 9,000 & 7,300 & 9,800 \\
\hline 49.6 & 22.5 & 65.3 & 19.9. & 110 & 33.3 & 191 & 107 \\
\hline 0.24 & 0.12 & 3.17 & 2.00 & $\tilde{c} .64$ & 1.89 & 2.42 & 1.69 \\
\hline 3.04 & 3.01 & 2.95 & 3.00 & $\widetilde{c .65}$ & 2.79 & 2.70 & $2.81^{\circ}$ \\
\hline 1.50 & 2.01 & 1.21 & 1.64 & 0.97 & 1.37 & 1.08 & 1.50 \\
\hline 0.31 & 0.41 & 0.24 & 0.34 & 0.15 & 0.22 & 0.17 & 0.24 \\
\hline 0.15. & 0.31 & 0.09 & 0.18 & 0.05 & 0.10 & 0.06 & 0.12 \\
\hline 5.00 & 5.74. & 4.49 & 5.16 & 3.82 & 4.48 & 4.01 & 4.67 \\
\hline
\end{tabular}




\section{BIBLIOGRAPHY}

1. Babcock, D. F., et al. An Evaluation of Heavy Water Moderated Power Reactors - A Status Report as of March 1963. E. I. du Pont de Nemours \& Co., Savannah River Laboratory, A1ken, S. C. USAEC Report DP-830 (1963).

2. Wade, J.W. A Computer Program for Economic Studies of Heavy Water Power Reactors. E. I. du Pont de Nemours \& Co., Savannah River Laboratory, Aiken, S. C., USAEC Report DP-707 (1962).

3. Large Reactor Study for Sea Water Distillation - Final Report. Bechtel Corporation, San Franc1sco, July 1963.

4. Saline Water Conversion Power Reactor Plants. Sargent \& Lundy, Englneers, Chicago, IIl. USAEC Report SL-1998 (1963).

5. Isakoff, L. and R. R. Hood, comp. Heavy Water Moderated Power Keactors - Progress Report - November 1962. E. I. du Pont de Nemours \& Co., AED, W1lmington, Del. USAEC Report DP-805 (1962).

6. Isakoff, L. and H. F. Measley, comp. Heavy Water Moderated Power Reactor - Progress Report - October 1962. E. I. du Pont de Nemours \& Co., AED, W1lmington, Del. USAEC Report DP-795 (1962).

7. Englneerlng Studies - Heavy Water Moderated Power Reactor Plants. Sargent \& Lundy, Engineers, Ch1cago, IIl. USAEC Report SL-2008 (1963). 